\title{
Improving Electric Vehicle Performance Using Photovoltaic Cells
}

\author{
Essam M. Allam*, Sameh M. Metwalley, Noha Muhammad \\ Automotive and Tractors Engineering, Faculty of Engineering, Helwan University, Cairo, Egypt \\ Email: *metwalley1965@hotmail.com, emmorsy@hotmail.com
}

How to cite this paper: Allam, E.M., Metwalley, S.M. and Muhammad, N. (2018) Improving Electric Vehicle Performance Using Photovoltaic Cells. International Journal of Clean Coal and Energy, 7, 1-19. https://doi.org/10.4236/ijcce.2018.71001

Received: January 6, 2018

Accepted: February 24, 2018

Published: February 27, 2018

Copyright $\odot 2018$ by authors and Scientific Research Publishing Inc. This work is licensed under the Creative Commons Attribution International License (CC BY 4.0).

http://creativecommons.org/licenses/by/4.0/

c) (i) Open Access

\begin{abstract}
Nowadays, the new trend in automotive industry is the transfer to electric vehicles due to many advantages such as no noise, no pollution, saving energy and reducing carbon dioxide emissions and it is a power-driven vehicle with a motor drive wheels moving. Solar electric vehicle reduces the greenhouse gas emissions and other pollutants. This paper presents the results of measuring the range and performance of the Electric vehicles as an alternative solution for fossil fuels based on previous work. It also presents the same measured parameters for the photovoltaic cells. A comparison between the two models has been done. It demonstrates a dynamic model of an electric vehicle and photovoltaic cell using the SIMULINK in MATLAB program. It explains the method of changing the hybrid car model to electric car model. However, the second model was for the photovoltaic cell. It shows the behavior of the two models separately and combined together. The experimental work has been performed through a single seated vehicle equipped with an electric and photovoltaic cell also separately and combined together. A verification of the two models was made. The results showed that the performance of the photovoltaic model is better than the electric model. The working time of the vehicle equipped with a photovoltaic cell is enhanced by $25 \%$ of the electric vehicle.
\end{abstract}

\section{Keywords}

Photovoltaic (PV), Solar Energy, Electric Vehicles (EV) and Electric Solar Vehicles (ESV)

\section{Introduction}

The unsustainable nature of fossil fuel and its horrendous effect on the environment create concerns to find an environment friendly alternative energy source is increasing exponentially. Quest of finding environment friendly energy 
source showed the alternatives of all fuel types and energy carriers types renewable energy sources like sun, wind, tides, hydropower and biomass which are safe, clean and different from fossil fuel. All renewable energy sources are effective but solar energy is the most sustainable source that will provide this energy forever. Photovoltaic cell efficiency is booming annually as new ideas with new technology keeps improving every year and production of photovoltaic panels is now more than ever before. Now it is the fastest growing alternative energy source of all renewable energy sources. So, considering improvement in solar energy technology, growth, efficiency and effectiveness should implement this technology as environment friendly and also sustainable source of energy. In last few years, lots of researches have been conducted and increasing attention has been spent towards the applications of solar energy on car. Various solar cars have been built and tested. In spite of a significant technological effort and some spectacular outcomes, several limitations, such as low power density, energetic drawbacks, weight, fuel savings and cost, cause pure solar cars to be still far from practical feasibility. Figure 1 shows a block diagram of solar vehicle components.

The reasons for studying and developing an Electric Solar Vehicle can be summarized as follows: [1] [2]

1) The great increasing in $\mathrm{CO}_{2}$ emissions produced from transport as clearly shown in Figure 2.

2) Oil price is increasingly growing day by day. Besides, it is subjected to large and un-predictive oscillations.

3) The increasing of both fuel consumption and population are regarded as a main worldwide demand for personal mobility as shown in Figure 3.

4) Climate change: Conventional vehicles produce very large amount of $\mathrm{CO}_{2}$. As result, increasing of temperature, pollution and climate change is greatly expected.

5) Solar cars, powered only by sun, don't represent a practical alternative to conventional cars. It has: limited power and performance, limited range, discontinuous energy source. Finally, Electric Solar Vehicles (ESV) combines advantages of both electric vehicle and photovoltaic cells. It can achieve the lowest

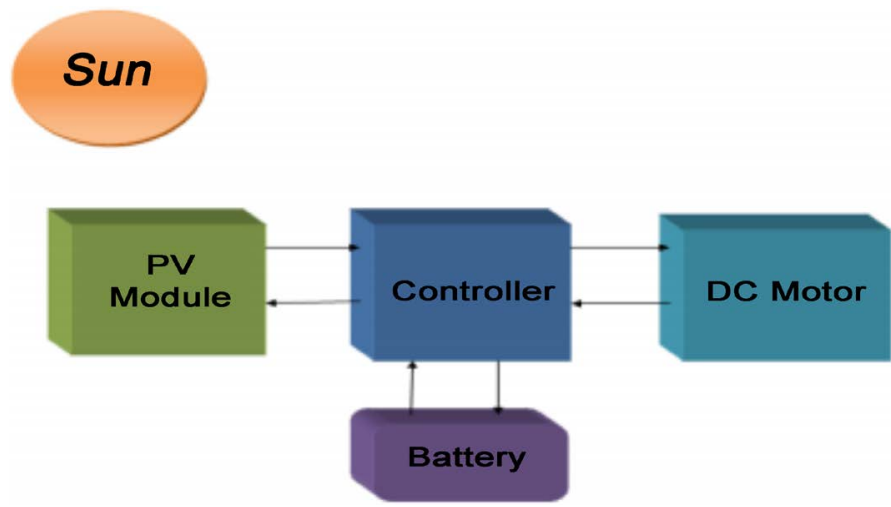

Figure 1. Block diagram of a solar vehicle components. 


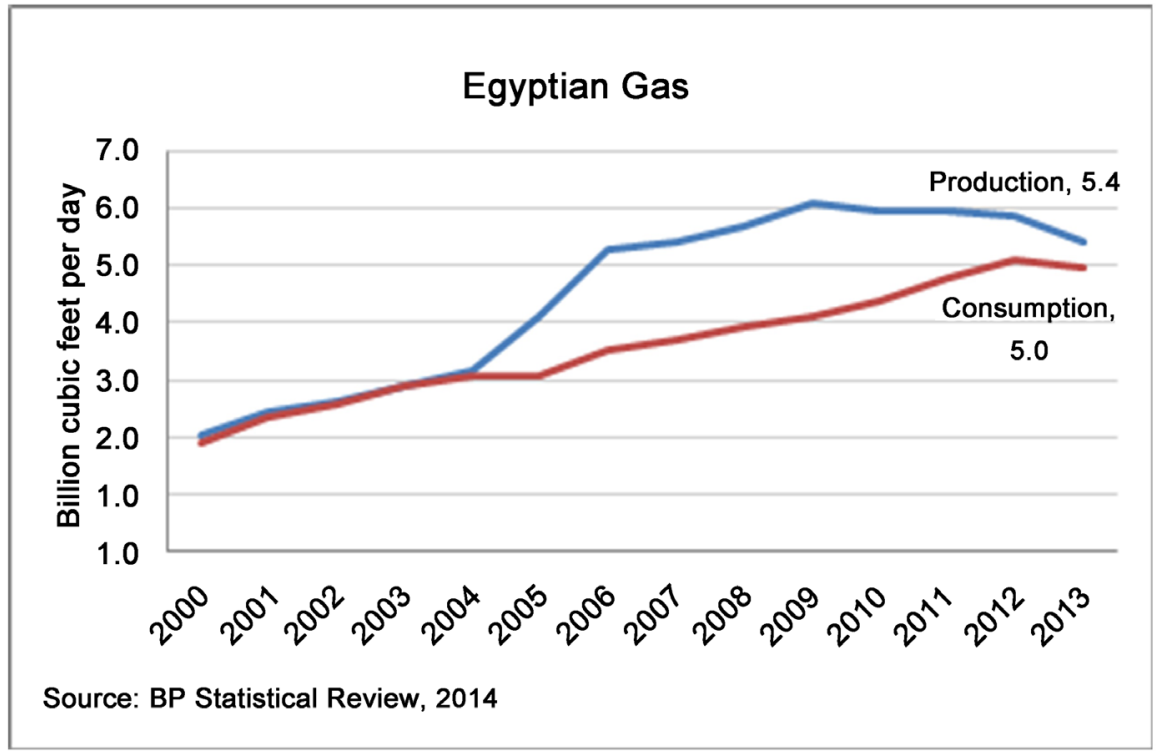

Figure 2. Oil production and consumption [3].

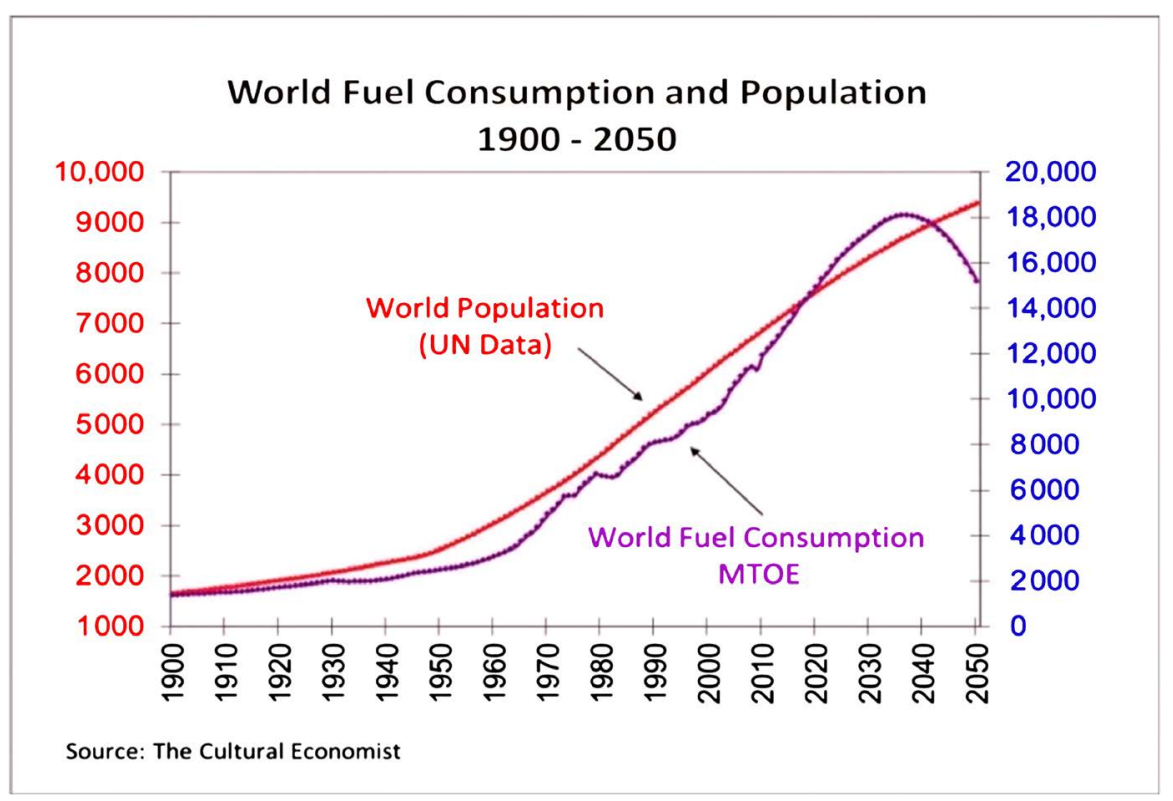

Figure 3. World fuel consumption and population [4].

possible fuel consumption for its movement by PV modules as an electricity source, and it also can reduce pollution.

The principal reason of Photovoltaic (PV) system is producing electric energy directly from solar radiation. It is becoming widespread as their advantages become apparent and as costs fall. Figure 4 shows that the installation of Photovoltaic panels is a remarkable increasing till 2015, and their cost is in a continuous decreasing.

So, the necessity shows the need of a tool or system that can evaluate overall performance of a solar car in different performance conditions. Therefore, a dynamic model of solar car can be developed to validate the characteristics of 


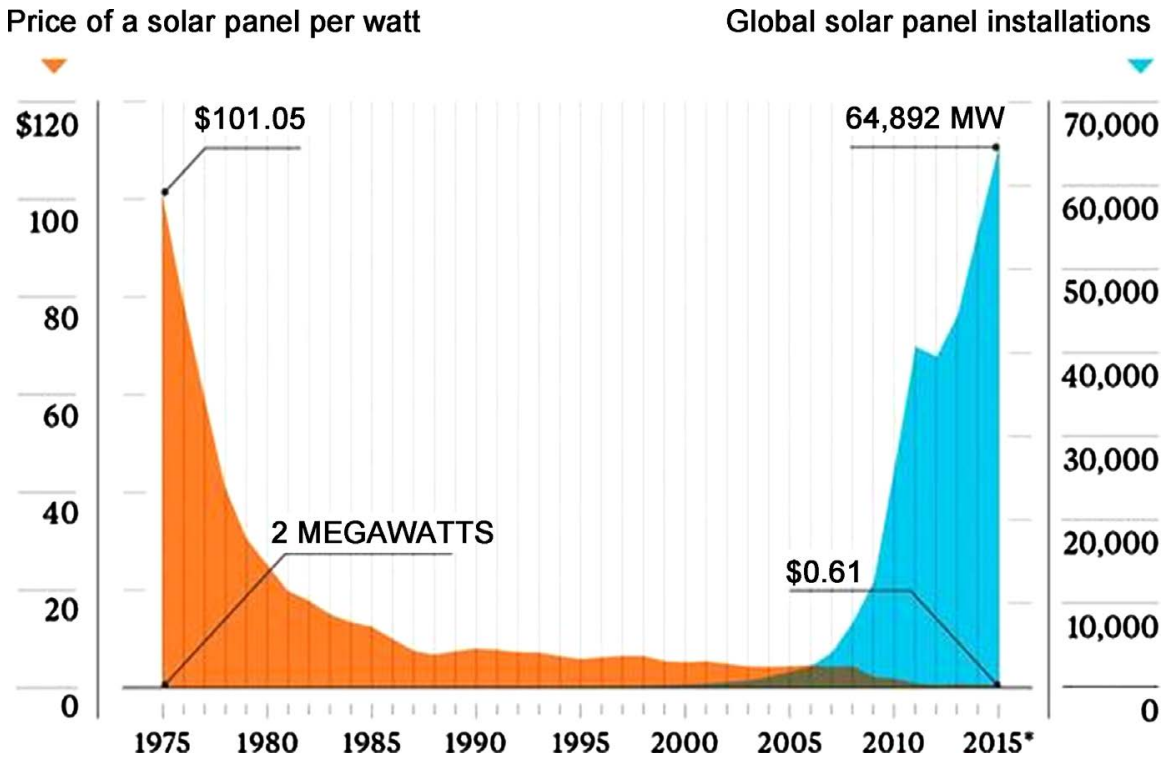

Figure 4. PV Cost and Installation [5].

different components of car along with the capability of evaluating its overall performance in a user friendly simulation environment of SIMULINK. Typically, the number of the cars used in the field of study is electrical vehicles, solar energy and photovoltaic cells.

\subsection{Electric Vehicle}

The electric vehicle operates on an electric/current principle. It uses a battery pack (batteries) to provide power for an electric motor. The motor uses the received power (voltage) from the batteries to rotate a transmission and turns vehicle's wheels [6] [7]. The electric vehicle consists mainly of four main parts as: the potentiometer, batteries, direct current (DC) controller, and motor as shown clearly in Figure 5.

The electric vehicle has many advantages such as fuel can be harnessed from any source of electricity, which is available at homes and businesses. In addition to that it reduces hydrocarbon and carbon monoxide by $98 \%$ and generally reduces pollution. It does not produce emissions which is very important in urban cities. However, the disadvantages of the electric vehicle are limited in the distance that can be driven before the complete failure of the battery. Accessories such as air conditioning and radios drain the battery. Besides, it is very heavy because of the weight of its components such as batteries, electric motor, controllers and chargers. The components of electric vehicle are also very expensive which constrained its movement.

\subsection{Solar Energy}

It is fully known that the sun is the largest source of light and heat in life. Solar energy originates with the thermonuclear fusion reactions occurring in the sun. So, solar energy is the main source of the entire electromagnetic radiation such 


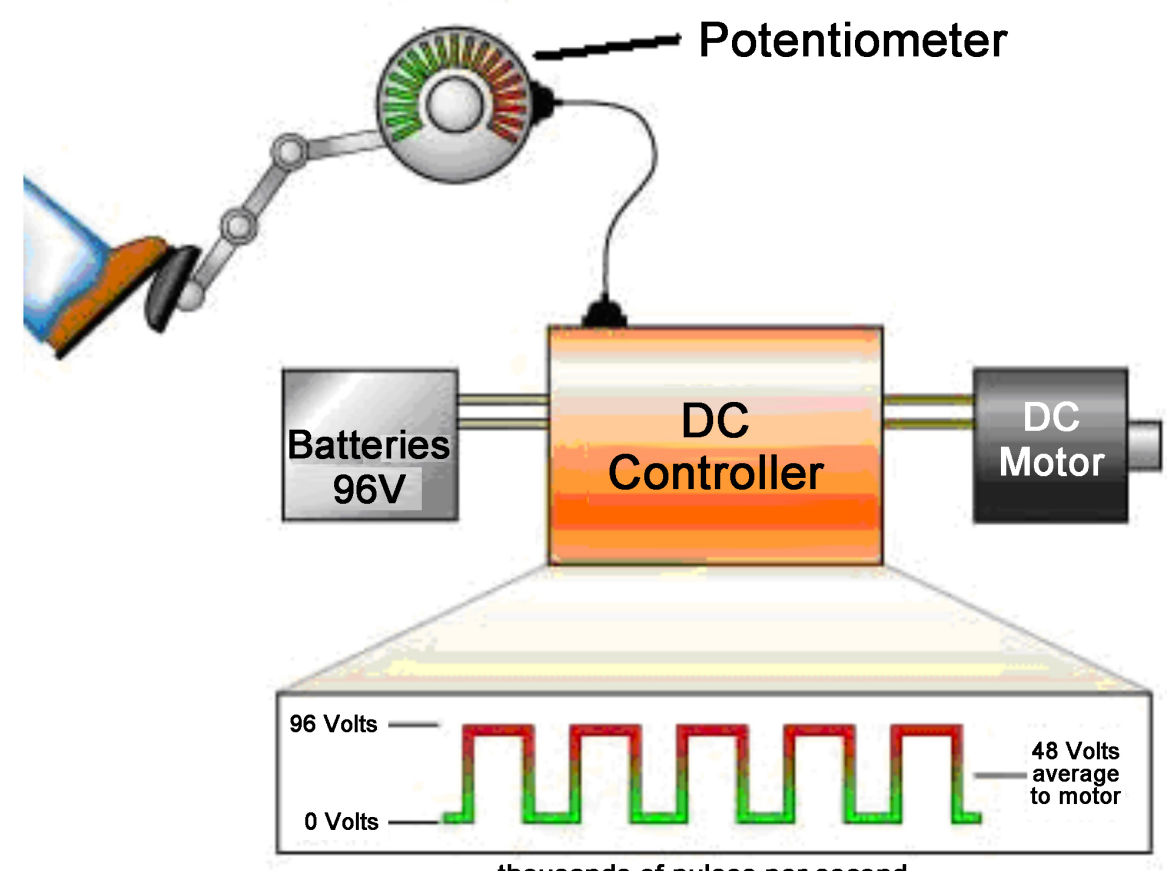

thousands of pulses per second

Figure 5. Electric vehicle components [6] [7].

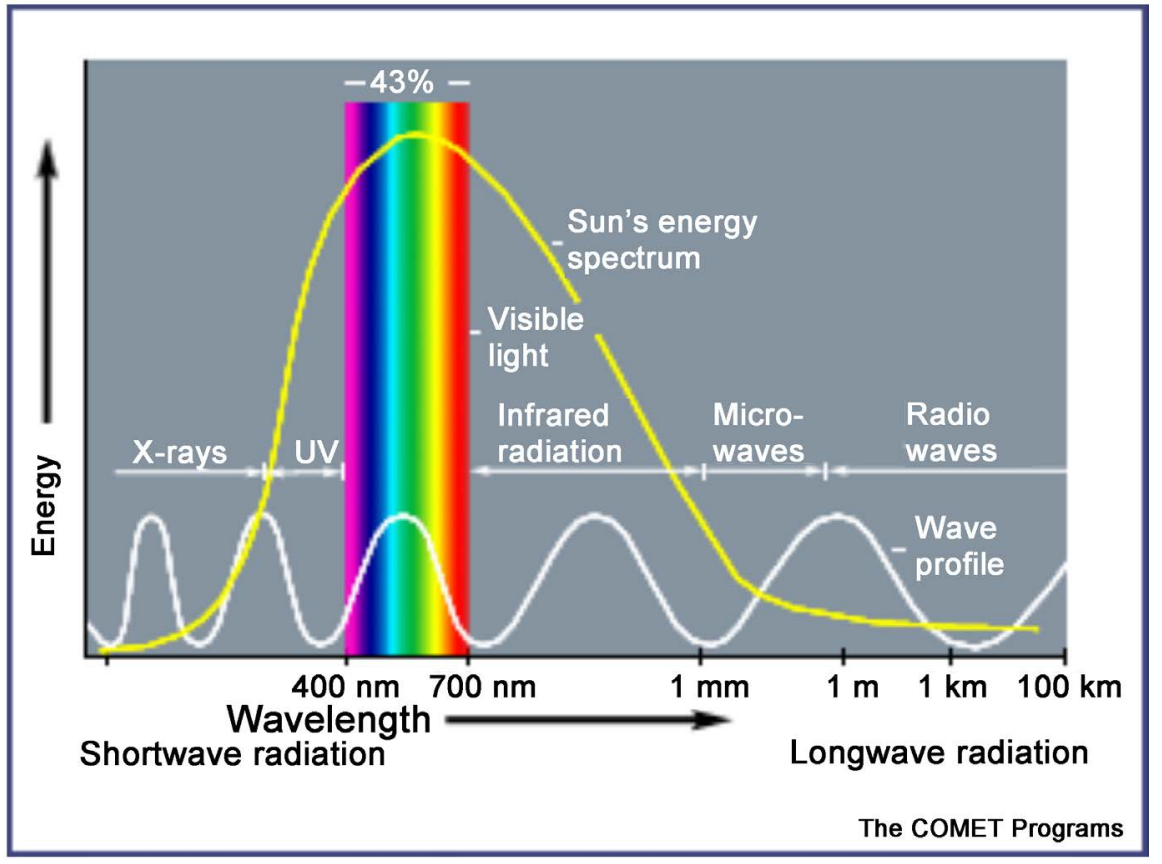

Figure 6. Energy distribution of sun solar waves [9].

as visible light, infrared, ultraviolet, $\mathrm{x}$-rays, and radio waves as shown in Figure 6. The sun radiates energy in space, the speed of light is received and reaches $300,000 \mathrm{~km} / \mathrm{s}$, and the solar radiation is absolutely necessary for the survival of any natural system vital. Out of all energy emitted by sun, only a small fraction of energy is absorbed by the earth and just tiny fraction of the sun's energy is enough to meet all of our power needs. 
Nowadays, solar technology is being used in so many aspects of lives such as: Architecture, urban planning, agriculture, solar lighting, solar thermal, water treatment and electrical generation etc. All of Solar vehicles are equipped with photovoltaic cells [8].

\subsection{Photovoltaic Cells}

Photovoltaic (PV) comprises the technology to convert sunlight directly into electricity. The term "photo" means light and "voltaic", means electricity. A photovoltaic (PV) cell, also known as "solar cell", is a semiconductor device that generates electricity [10], when light falls on it, Photovoltaic cells are used to convert solar radiation directly into electricity. Solar cell is made of two layers of semiconductor as shown in Figure 7 \& Figure 8, when light rays fall on the part of the cell; the light is absorbed by the silicon atoms as energy. This energy increases

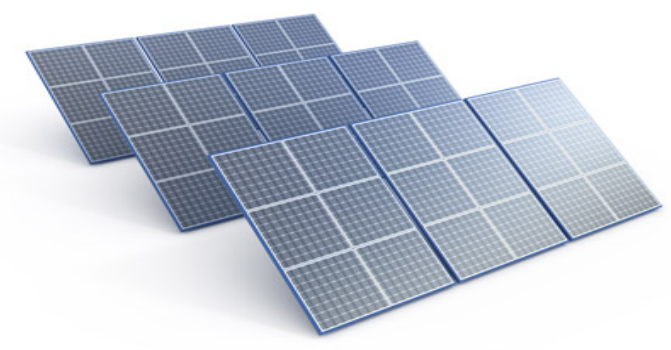

Figure 7. Solar panel [11].

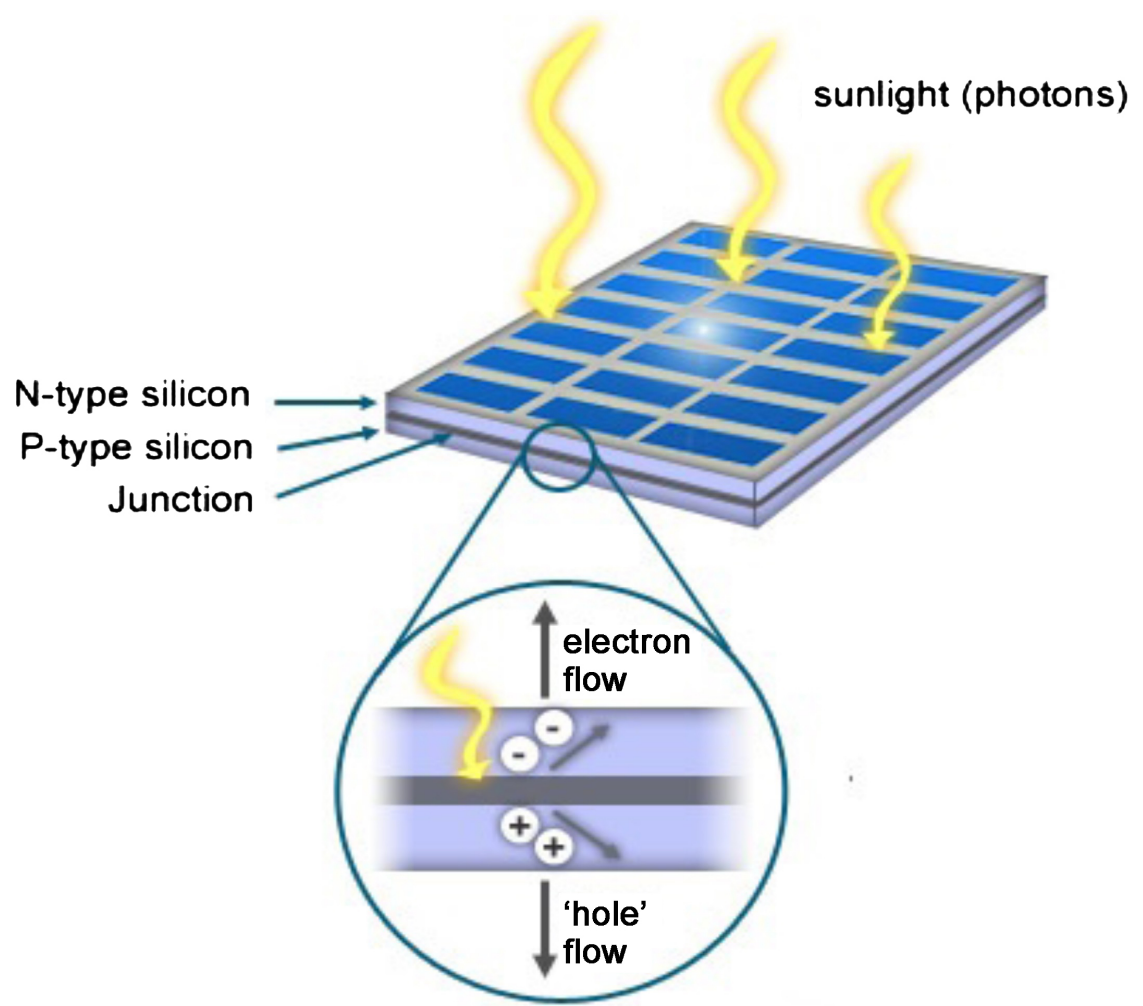

Figure 8. Photovoltaic effect. 
the number of electrons the electrons in the material which is associated with, and allows them to move freely inside the material. When the free electrons exposed to an electric field, it moves only in one direction generating an electric current.

Generally, there are three types of PV modules which are Mono-crystalline, Poly-crystalline and Thin-films. In the type of Mono-crystalline, the cell is made from a single silicon crystal. However, it is made from lots of silicon crystals in the Poly-crystalline type which is cheaper than the Mono-crystalline type and less in efficiency. Thin films type is made from less material and cheaper than the other two types and the efficiency is also less than the other two types.

Figure 9 shows the typical differences of different PV modules that indicates the Mono-crystalline type is more expensive than the other two types but more efficient than them [12].

Finally PV cells are environmentally friendly and already delivered for free everywhere. It is cheap, efficient, supplied with no limit source of energy. It also reduces pollution. In addition to all of that it is very safe and does not need maintenance or at least easy maintenance (replacement).

\section{Mathematical Model of a Complete Vehicle}

\subsection{Flowchart of the Algorithm for Photovoltaic Cell}

Figure 10 shows the parametric modeling flowchart of the Simulink (Algorithm). The steps of the algorithm contain three main steps which are:

- Preprocessor.

- Solution.

- Postprocessor.

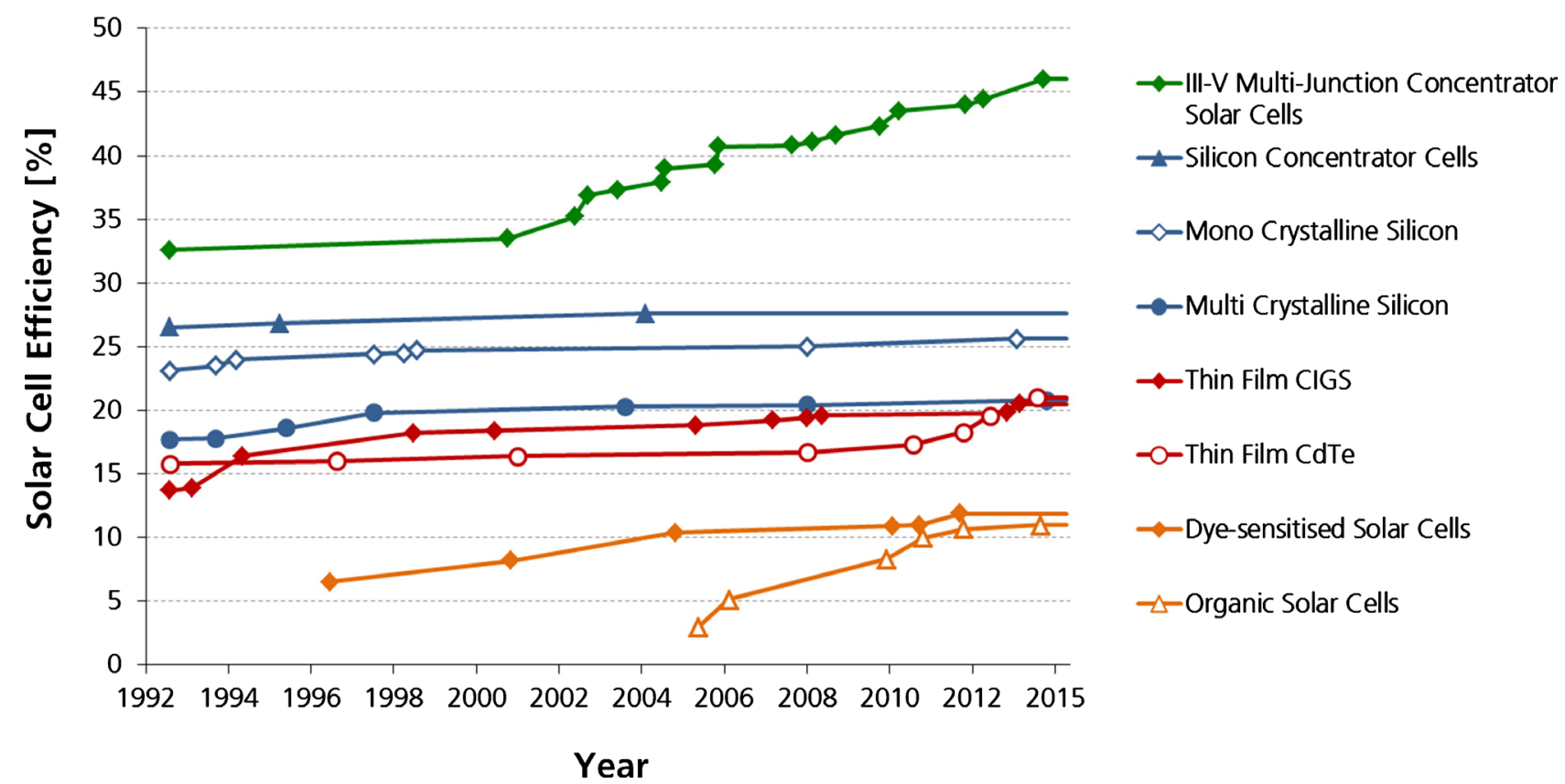

Figure 9. PV typical efficiencies [12]. 
The preprocessor step includes input data of PV cell which are volt V, Irradiance $\mathrm{G}_{\mathrm{a}}: 1 \mathrm{~W} / \mathrm{m}^{2}$, open circuit temperature Toc: $25+273$, cell resistance in parallel Rp: 360.002 , cell resistance in series Rs: 0.18 and number of cells (series and parallel) n: 1.36. However, solution step include the commands from the Simulink library to solve the problem of the paper. Finally, the postprocessor step includes the collecting data from the solution step to be represented as shown in Figures 13-20 for the case of PV only.

\subsection{Combining the Components}

Figure 11 shows a complete PV system for vehicle model. The output of the panel and the motor are connected to the battery via the controller as shown in the figure. The output of the battery is then sent to the workspace to be presented as described in the postprocessor step. The used PV cell runs under different ambient operating conditions as changing temperature and irradiance. The I-V and P-V characteristics of the panel are observed by changing the load. The test procedures were as follows;

1) All tests has been recorded and observed through a complete day in the

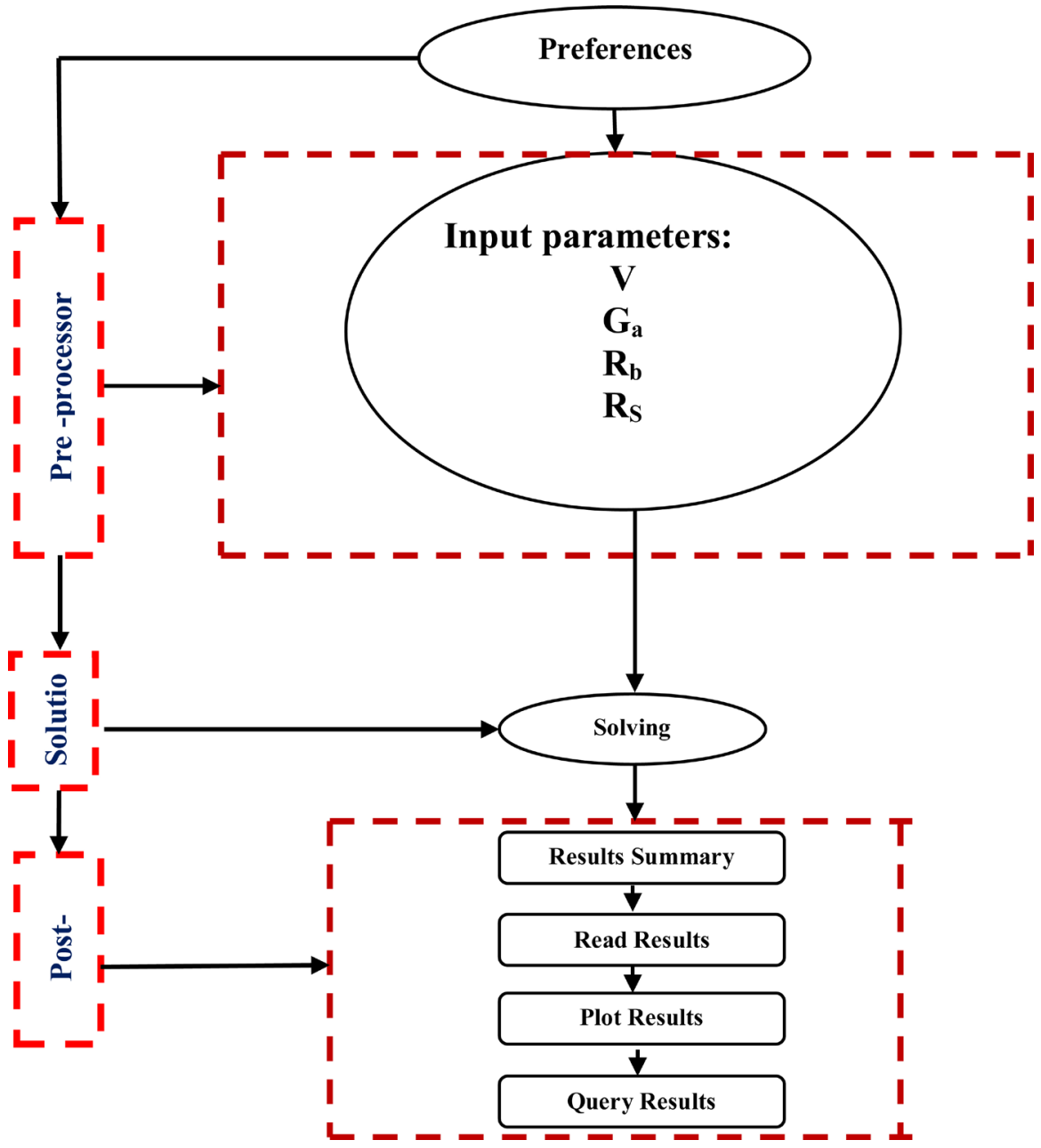

Figure 10. Flowchart of PV. 
summer.

2) The prototype car started the tests between two certain places for 8 hours.

3) The state of charge (SOC) is observed through the whole test in the day of experiment.

4) The initial SOC is set at $80 \%$.

\section{Experimental Setup}

A four wheel prototype for the car used in the experiments is shown in Figure 12. It shows an electric prototype car with a full steering, suspension and brake system. A photovoltaic cell of the poly-crystalline type has been added to the prototype model to charge the battery of the model as clearly shown in Figure 12. The model of the car was tested during the mid-day in the summer time for both electric car only and electric car with a photovoltaic cell and a record of the

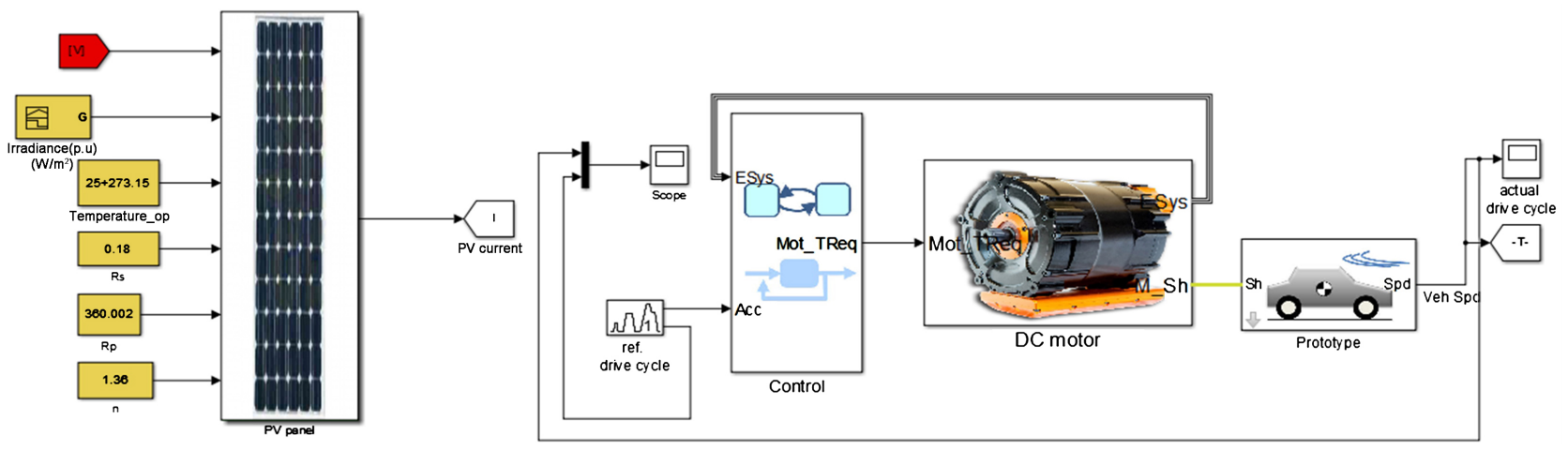

Figure 11. Complete PV vehicle model.

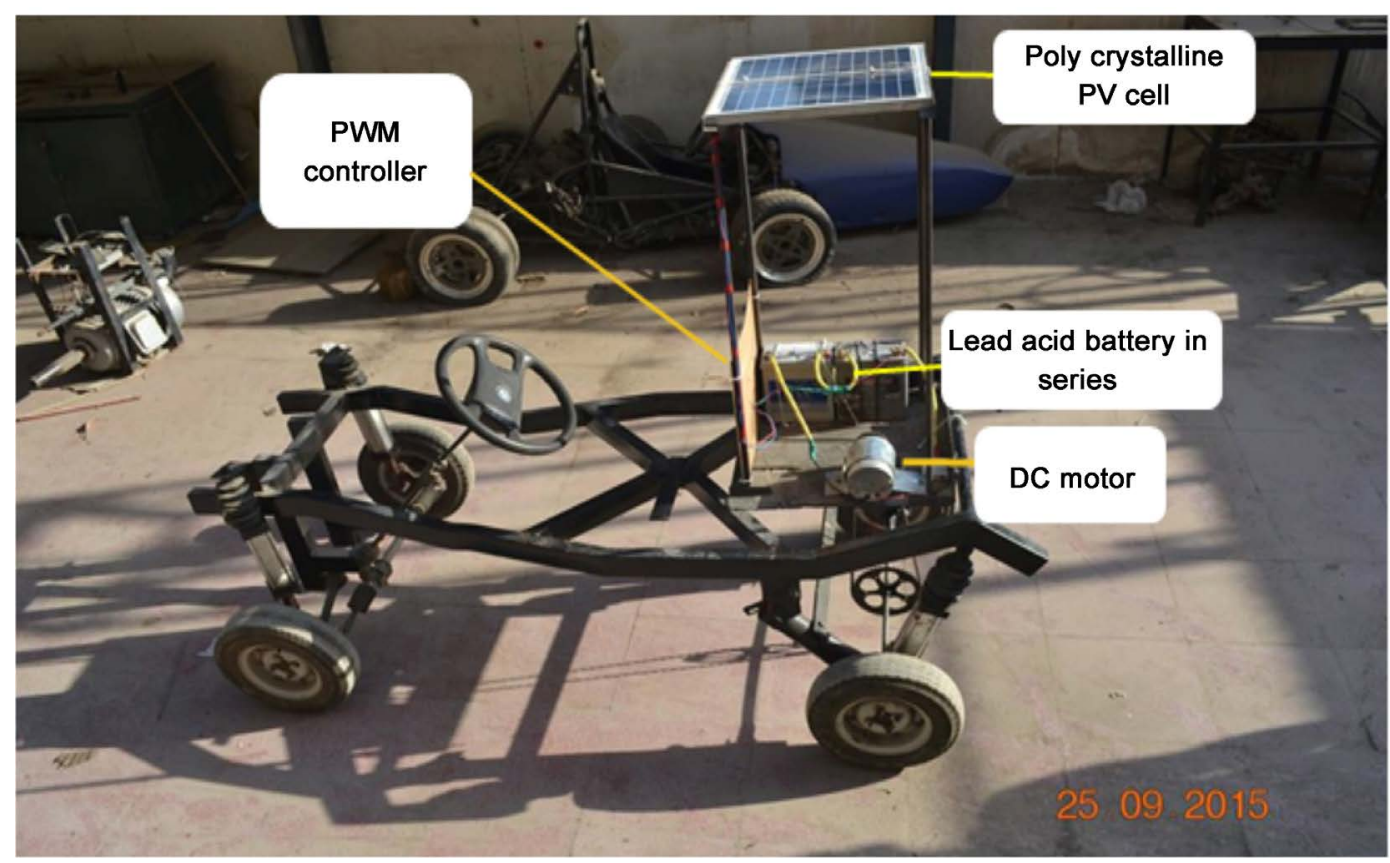

Figure 12. Final shape of prototype. 
range and time charging has been measured.

\section{Results and Discussions}

The results collected from the Simulink program and experiments and be presented in the next figures. Figure 13 shows the state of charge (SOC) against time in a summer day. It indicates that at time 8:30 AM the PV started with a charge of $64 \%$ and finished the test at 4:30 PM with a charge of $80 \%$. Figure 14

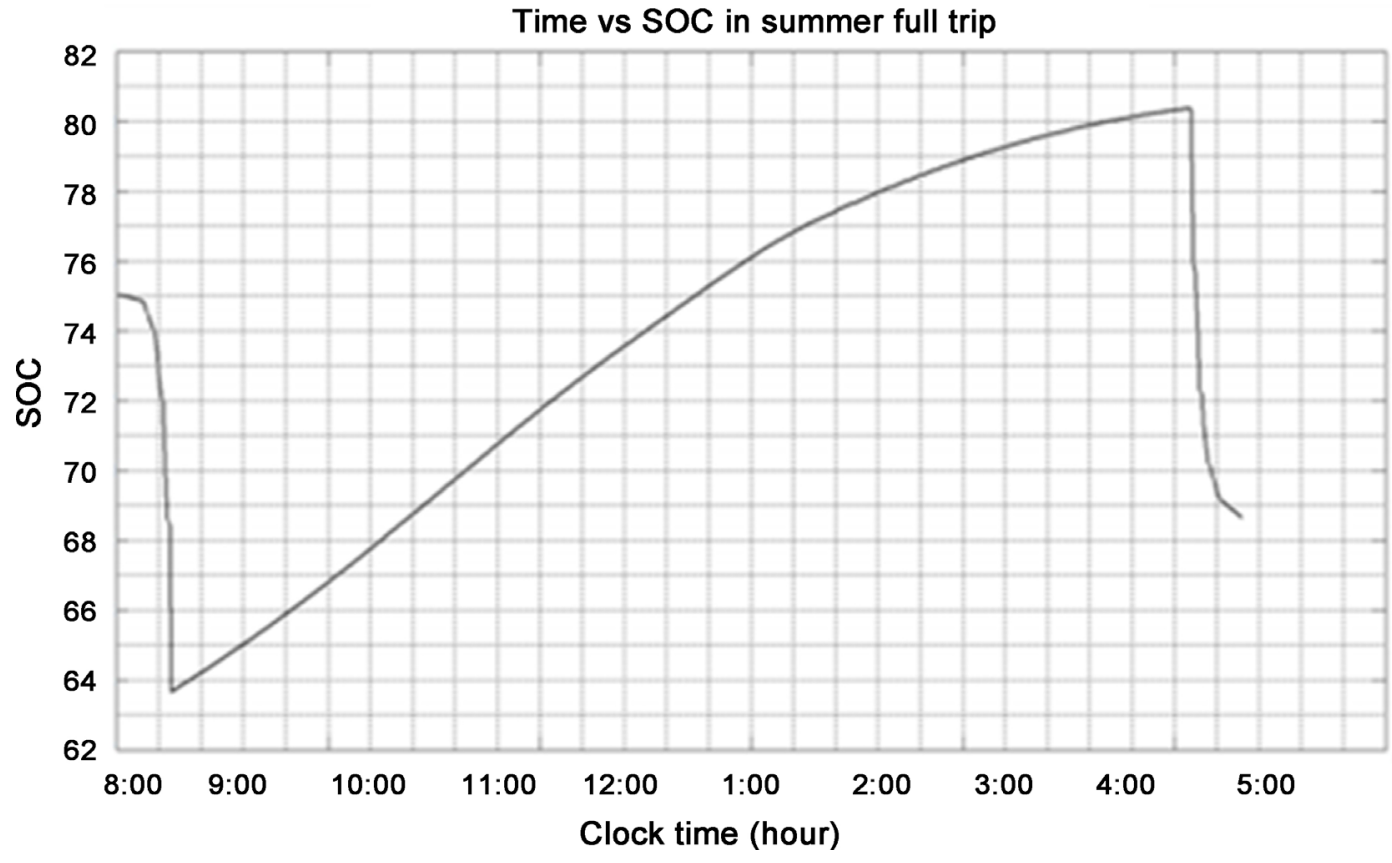

Figure 13 . SOC vs. time, at summer condition.

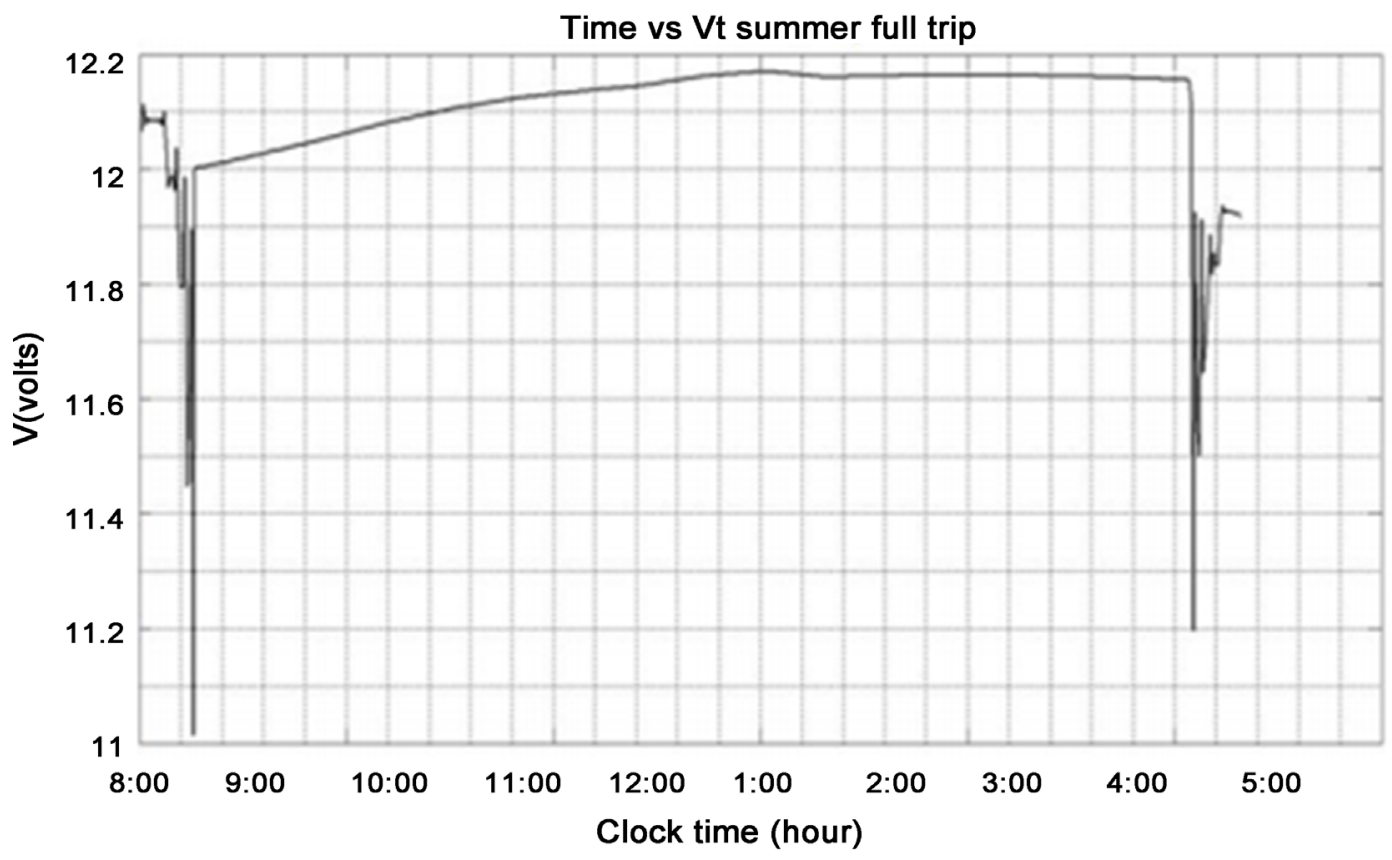

Figure 14. Volt vs. time, at summer condition. 
represents the volt against time for the same period between 8:30 AM and 4:30 PM in the same summer day and time. However, Figure 15, Figure 16 show the SOC against time and volt against time respectively but in a winter day test. It indicates that the charge for the battery in the summer day was quicker than the winter day. Figure 17, Figure 18 indicate day but without sun light.

\subsection{Effects of a Changing the Irradiance}

Figure 19(a) shows the current against voltage for a different irradiance for the

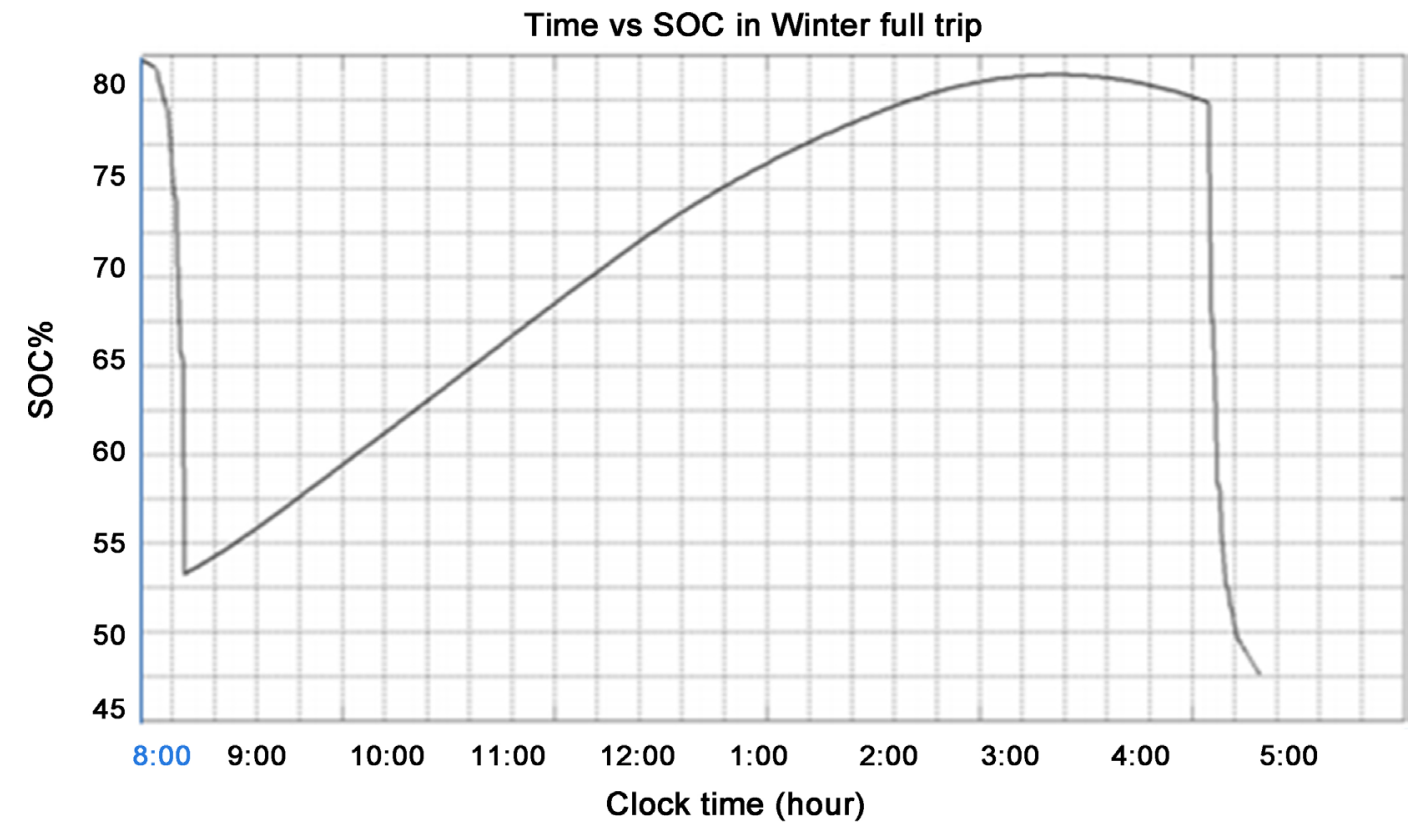

Figure 15. SOC vs. time, at winter condition.

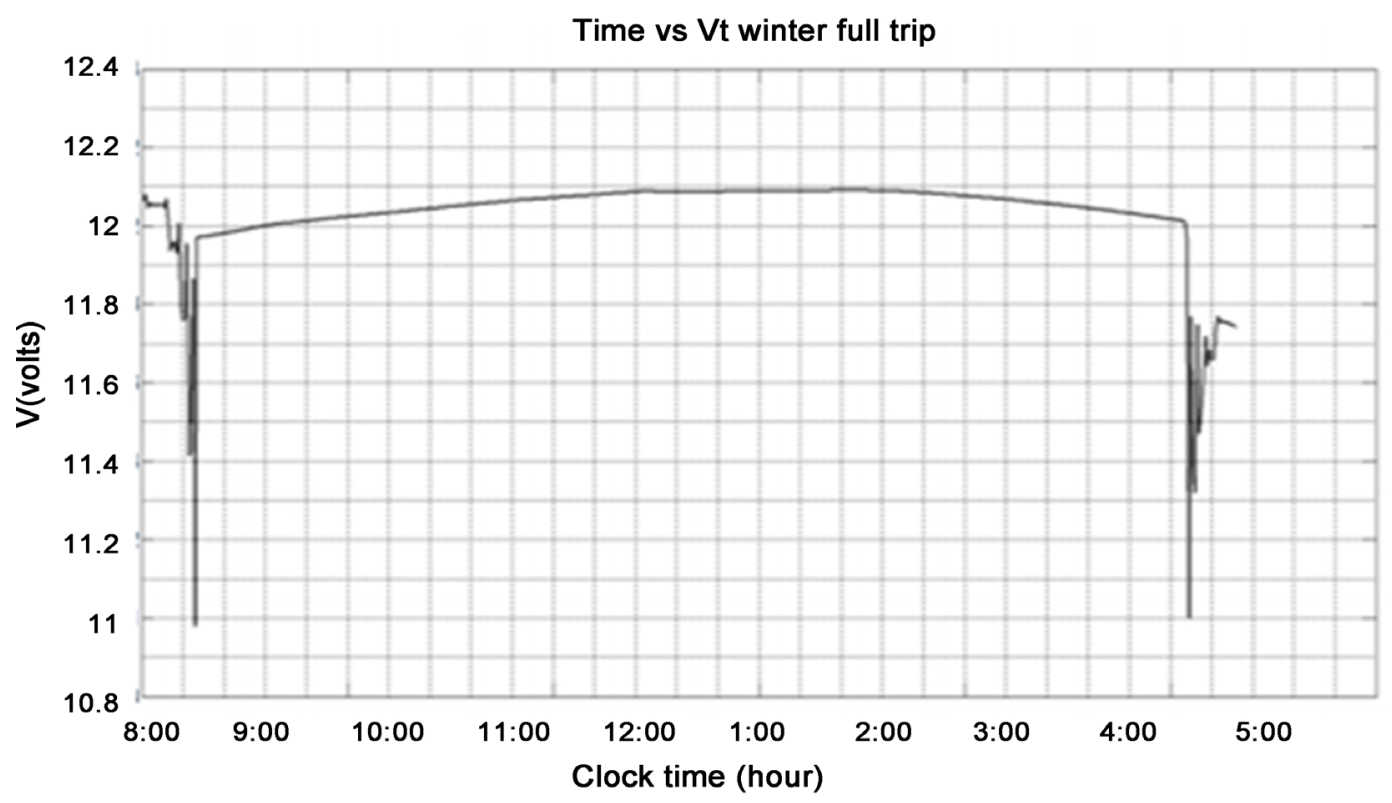

Figure 16. Volt vs. time, at winter condition. 


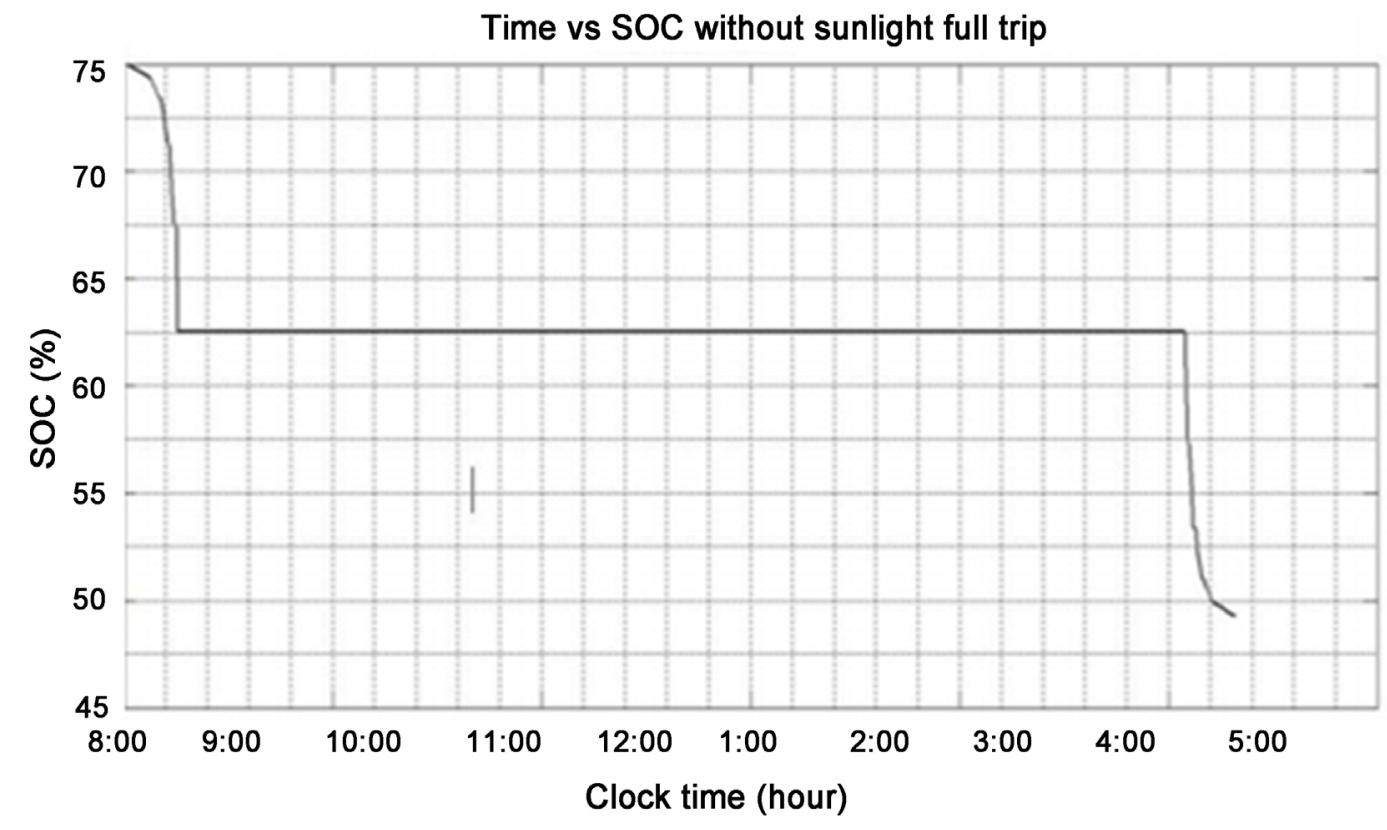

Figure 17. SOC vs. time, without sun light.

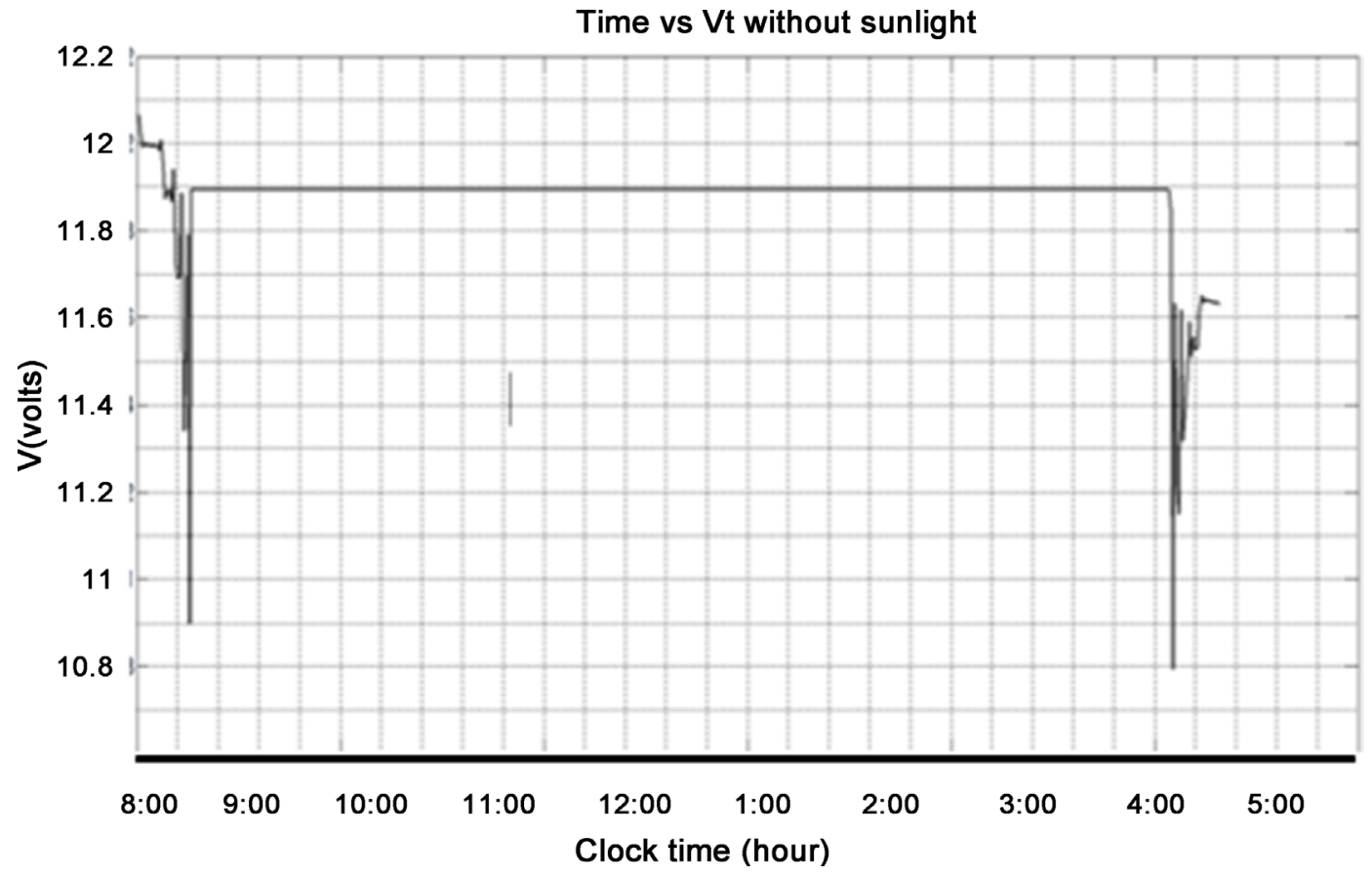

Figure 18. Volt vs. time.

poly-crystalline PV cell used in the test. The tests are for a series of irradiance between $200 \mathrm{w} / \mathrm{m}^{2}$ to $1200 \mathrm{w} / \mathrm{m}^{2}$ with a step of $200 \mathrm{w} / \mathrm{m}^{2}$. It shows that at 1200 $\mathrm{w} / \mathrm{m}^{2}$ the current is $6.3 \mathrm{Amp}$ so, the irradiance for the PV used is chosen as 1200 $\mathrm{w} / \mathrm{m}^{2}$. However, Figure 19(b) shows the power against voltage for the same variable irradiance between $200-1200 \mathrm{w} / \mathrm{m}^{2}$. It also confirms that for an irradiance of $1200 \mathrm{w} / \mathrm{m}^{2}$, it gives the best power and current for the poly-crystalline PV used in the tests. 


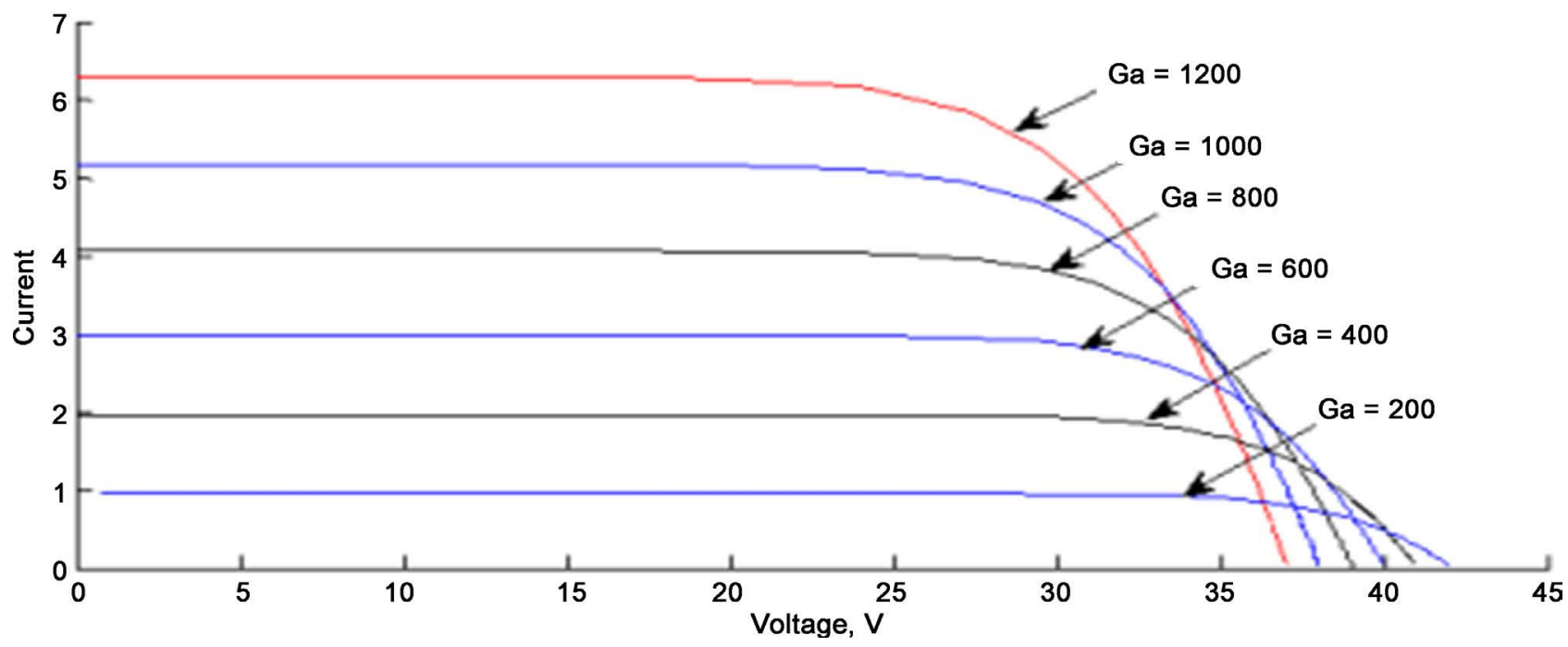

(a)

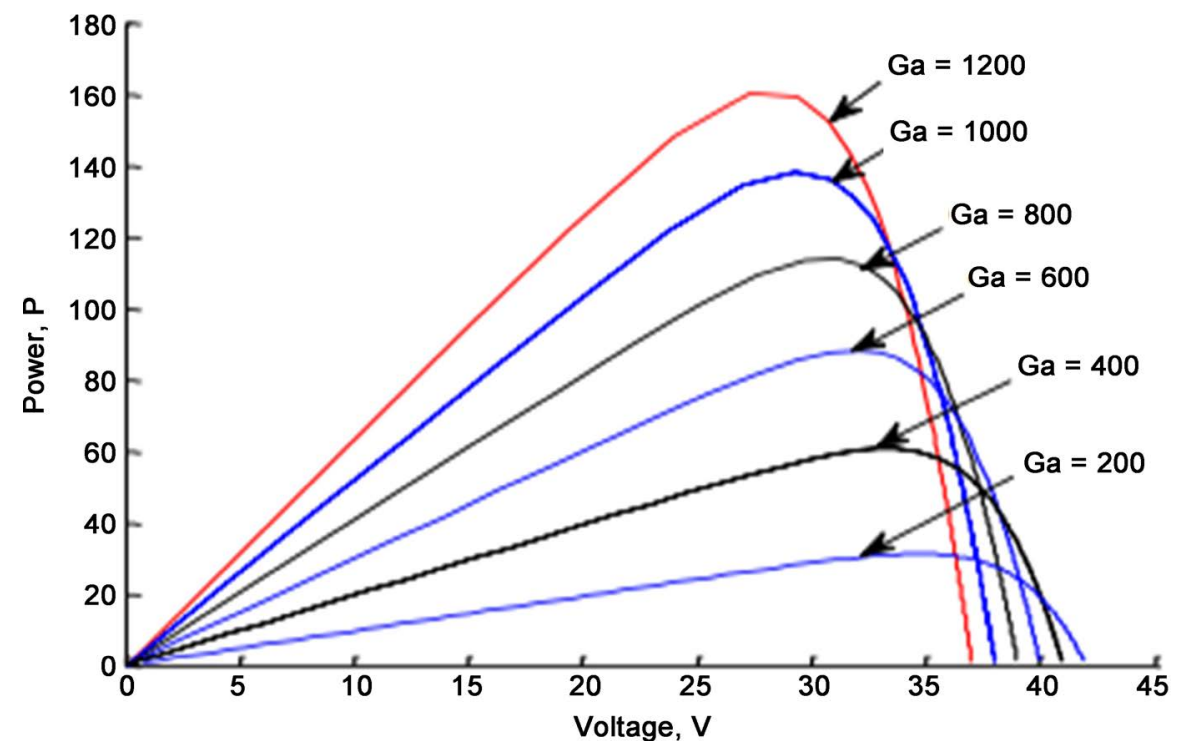

(b)

Figure 19. (a) IV curves under different irradiance; (b) PV curve under different irradiance.

\subsection{Effect of Changing Temperature}

Figure 20(a) shows the relationship between the current and the volt for a range of temperatures between $10^{\circ} \mathrm{C}$ to $50^{\circ} \mathrm{C}$. However Figure $20(\mathrm{~b})$ indicates the relationship between the power and volt for the same range of temperatures between $10^{\circ} \mathrm{C}$ to $50^{\circ} \mathrm{C}$ for the poly-crystalline PV cell used in the tests.

\subsection{Simulink Results}

As it is stated in the mathematical work in section 2, the program run for 8 hours between 8:30 AM and 4:30 PM. Figure 21 indicates the drive cycle of both internal combustion engine (ICE) and the electric vehicle (EV). It shows that the deviation between the two types of vehicles is very small. So, a highlighting on a small part of the drive cycle is shown in Figure 22. It indicates that the braking 


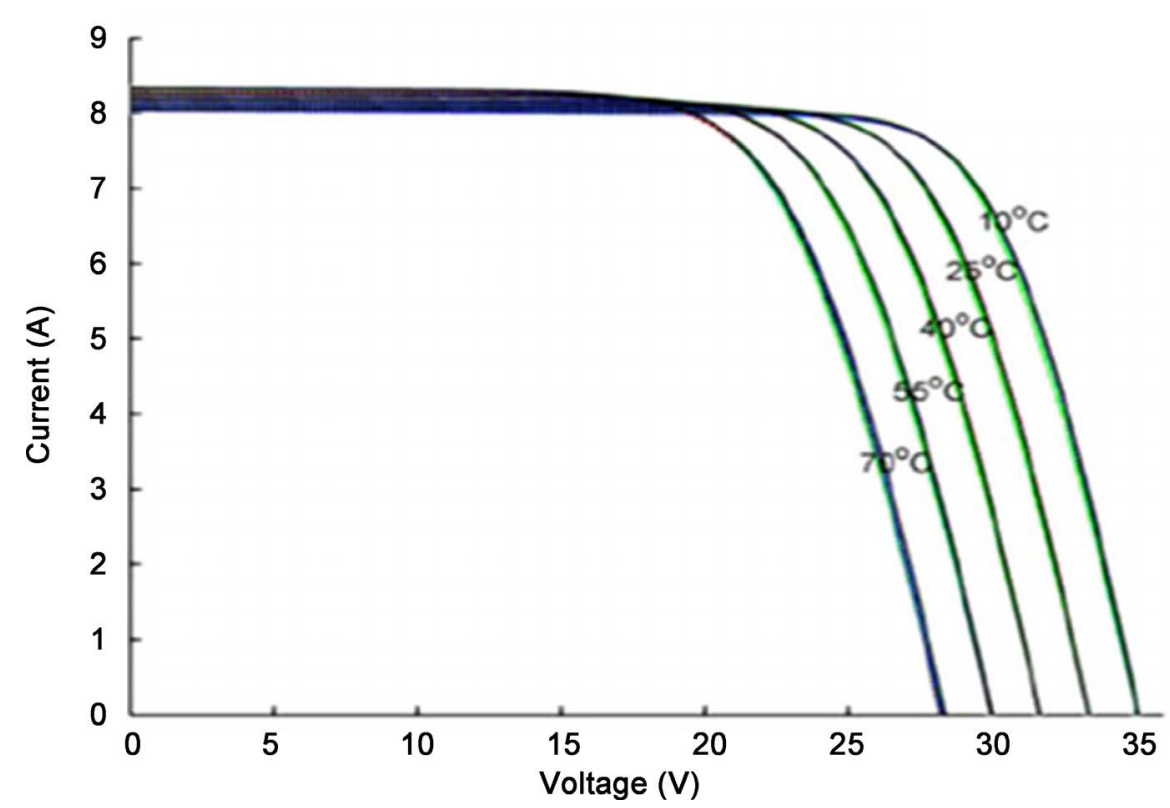

(a)

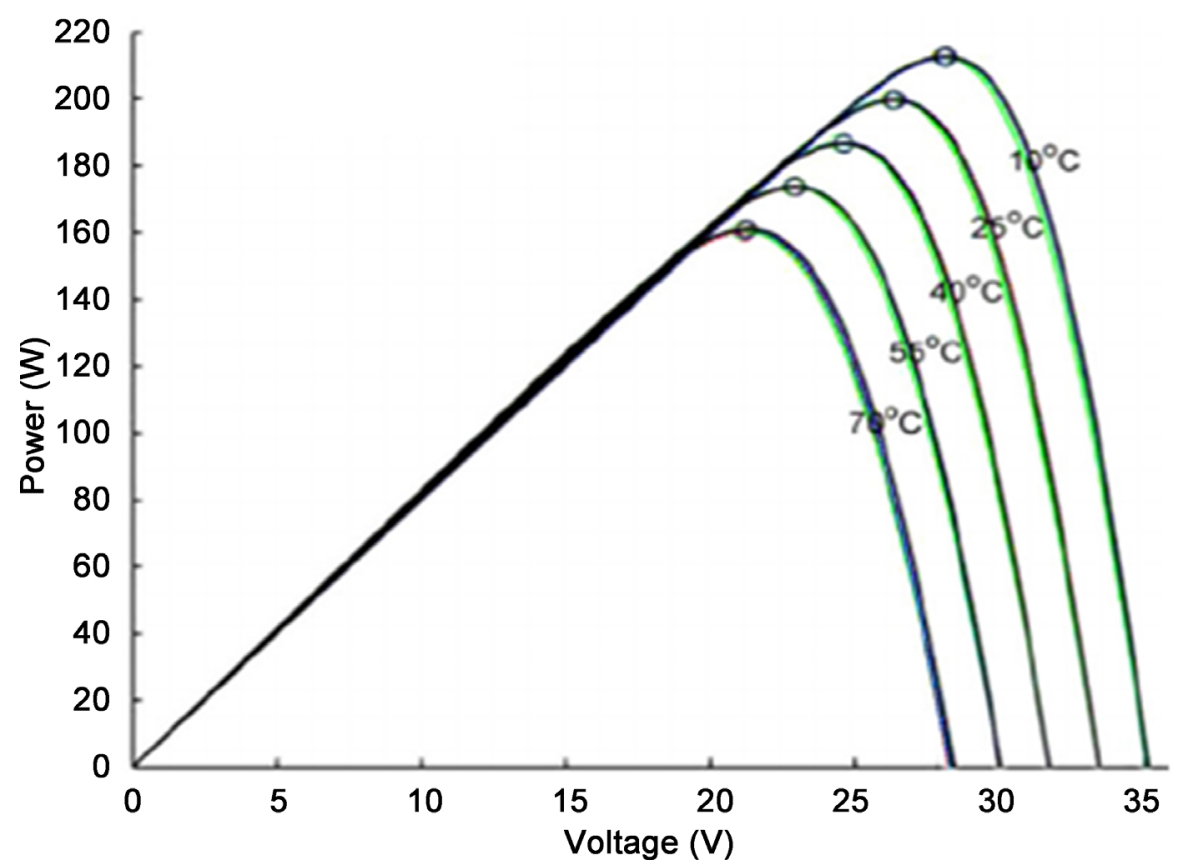

(b)

Figure 20. (a) IV curve under different temperatures; (b) PV curve under different temperatures.

performance of the EV is better than the ICE. However, the acceleration performance of ICE is better than EV to confirm that the motor power is less efficient than the engine power.

Figure 23 shows battery power consumption rate of electric vehicle during the drive cycle. So another highlighting on a small part of the drive cycle is shown in Figure 24. It indicates that the maximum power equals +1500 watt. The positive sign means that the battery discharges. 
Figure 25 indicates that the drive cycle of both ICE and PV. It shows that the deviation between the two types of vehicles is small. So, a highlighting also on a small part of the drive cycle is shown in Figure 26. It indicates that the braking performance of the PV is better than ICE. However, the acceleration for both of $\mathrm{PV}$ and ICE is equal to confirm that PV power has been developed.

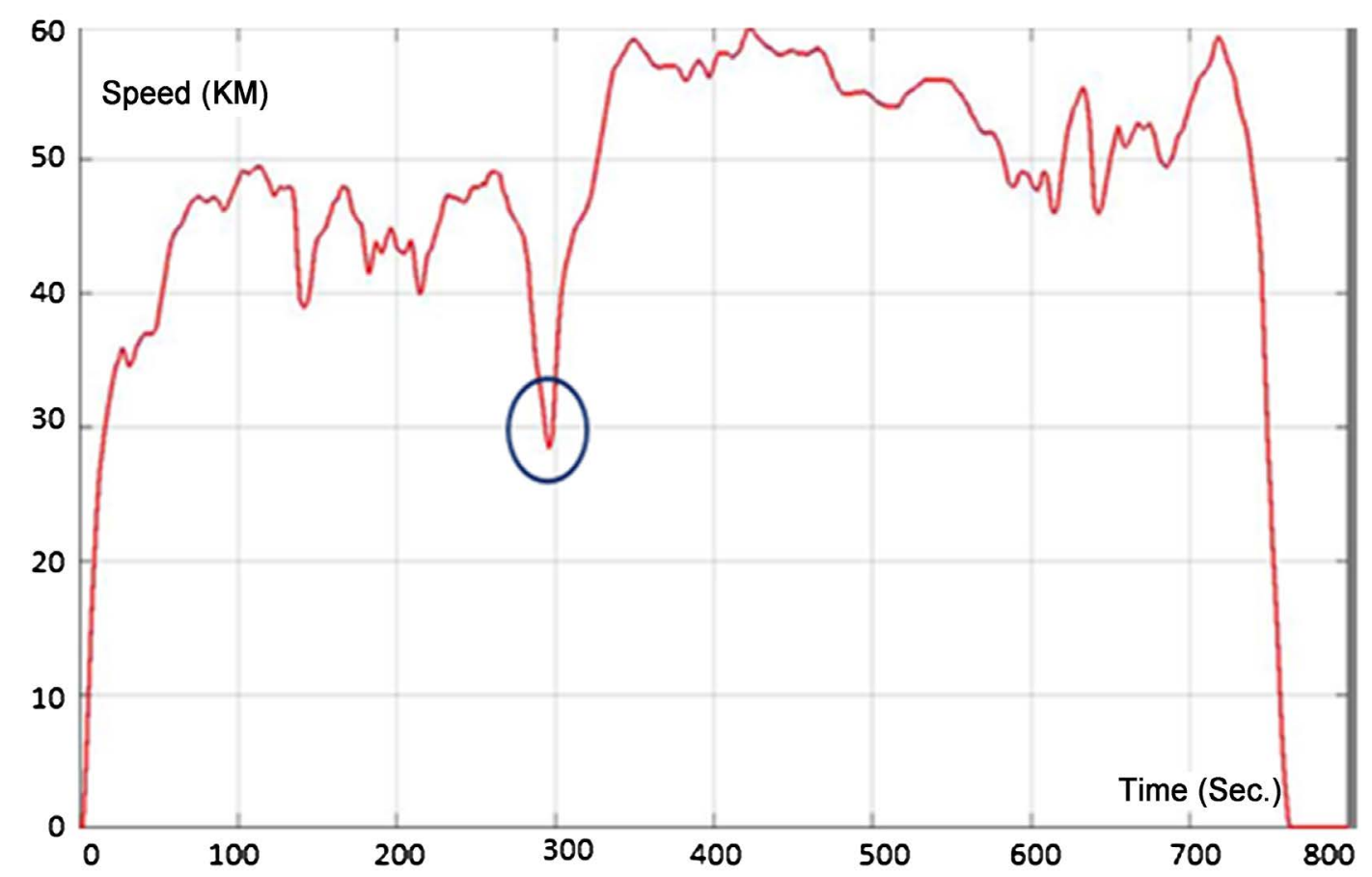

Figure 21. Drive cycle of IC vehicle and electric vehicle.

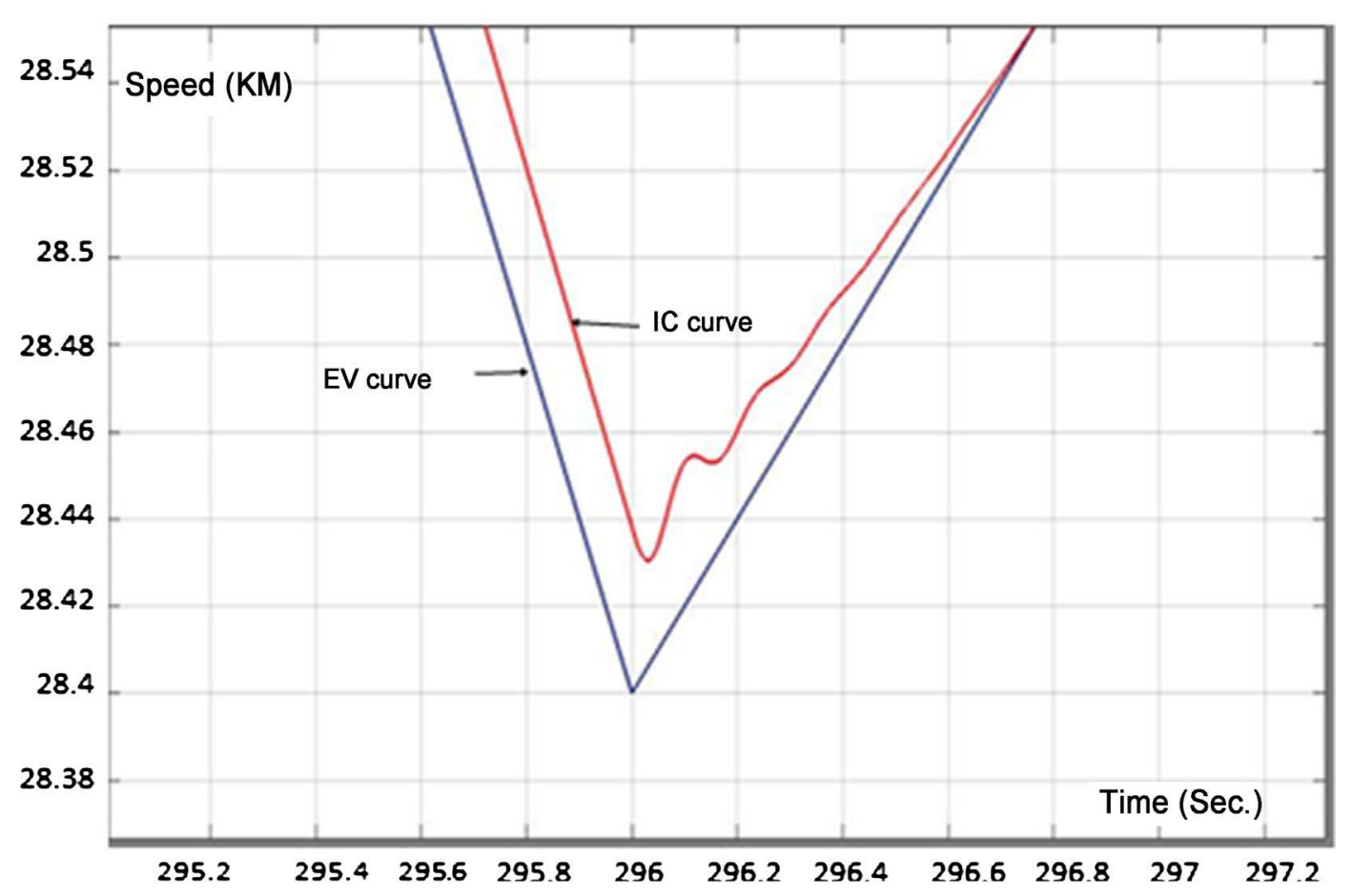

Figure 22. Zoom of the drive cycle. 


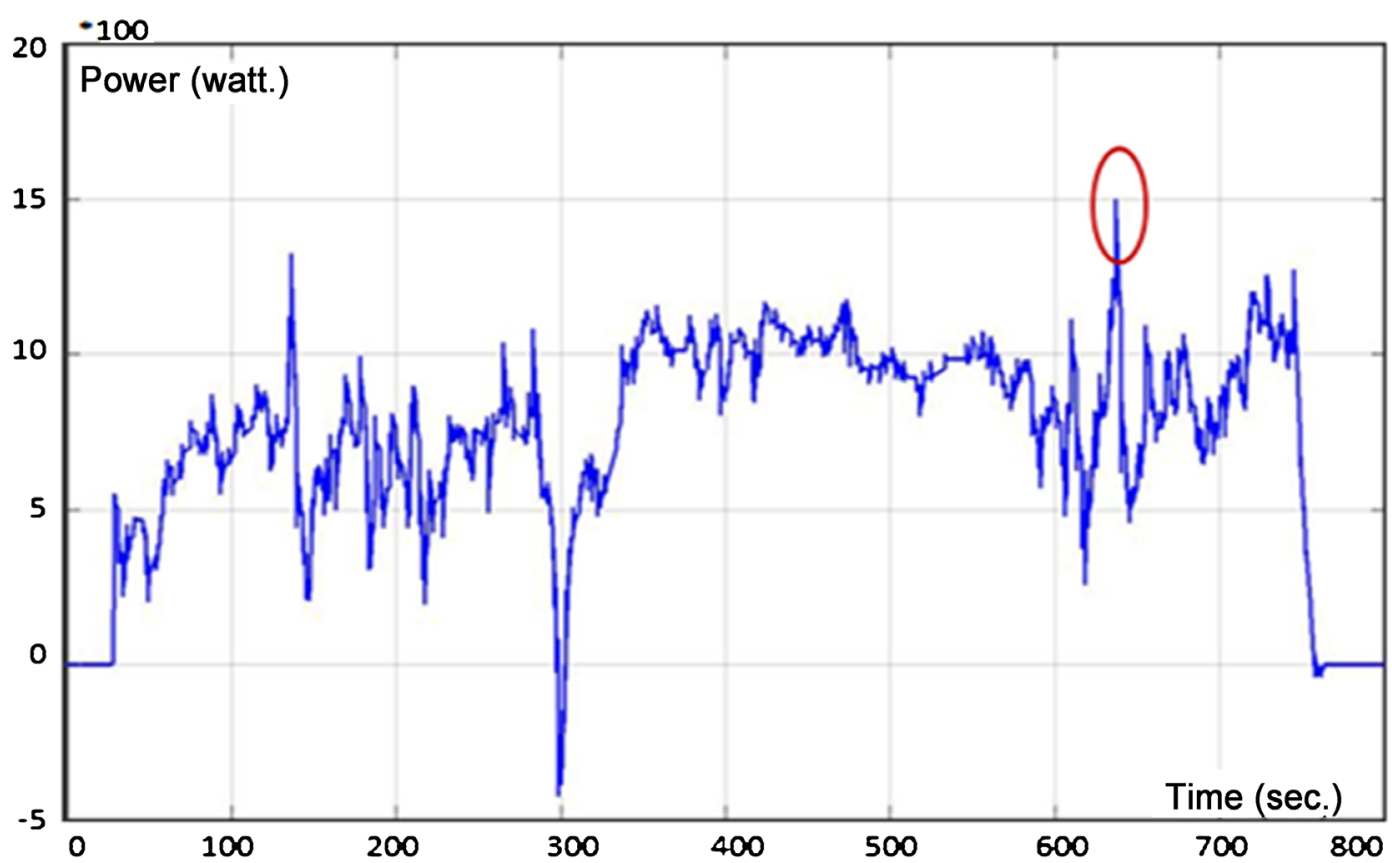

Figure 23. Electric vehicle battery power.

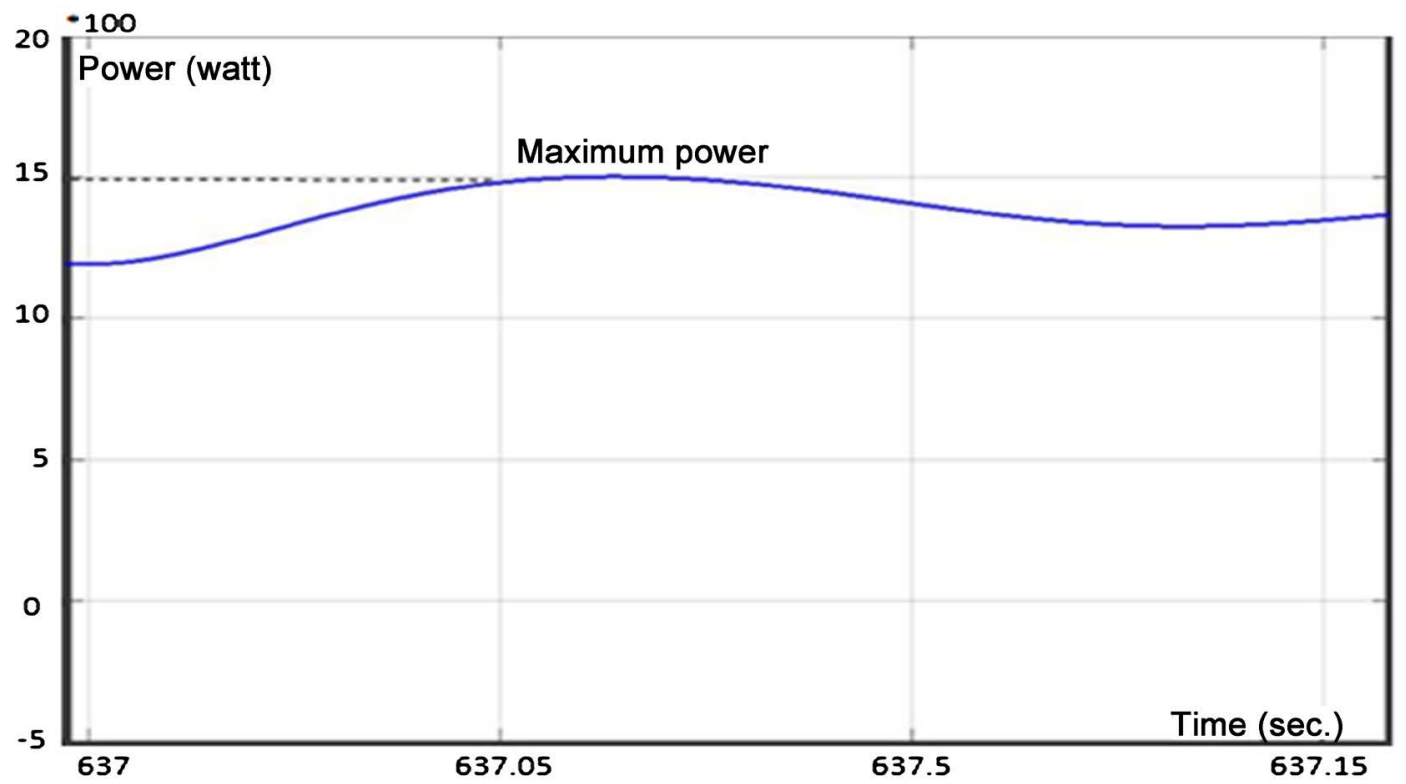

Figure 24. Zoom for battery power.

Figure 27 shows battery power consumption rate of photovoltaic vehicle during the drive cycle. So a highlighting again on a small part of the drive cycle is shown in Figure 28. It indicates that the maximum power equals -6500 watt. The negative sign indicates a direction not a value to confirm that the battery is charged by sun.

The difference between the PV and EV values of maximum power is the real saved battery power during charging.

$$
\mathrm{P}_{\mathrm{PV}}-\mathrm{P}_{\mathrm{EV}}=6500 \mathrm{~W}-1500 \mathrm{~W}=5000 \mathrm{~W}(5 \mathrm{KW}) \text {. }
$$




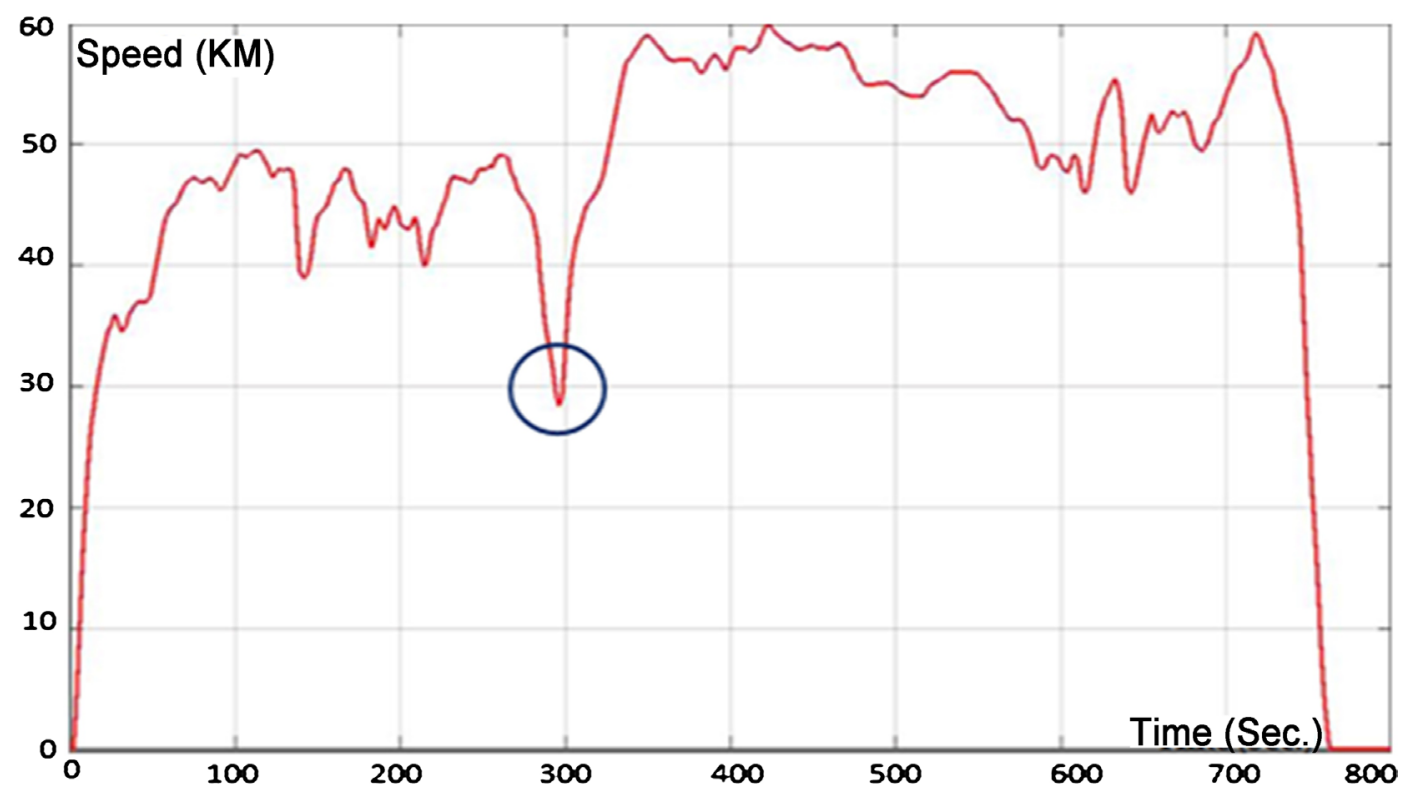

Figure 25. Drive cycle of IC vehicle and PV vehicle.

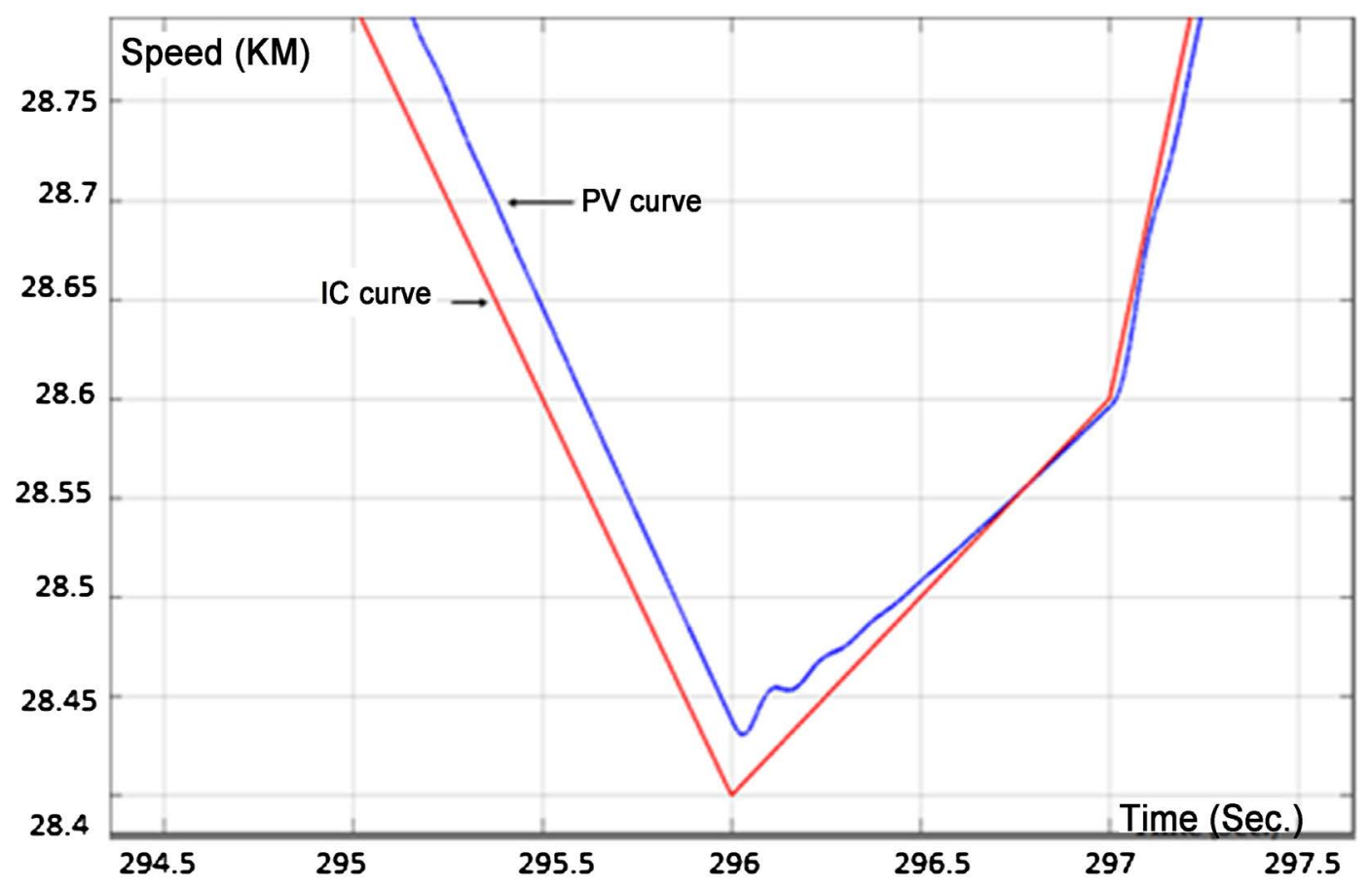

Figure 26. Zoom of drive cycle.

\subsection{Experimental Results}

As stated in Section 3, the prototype model of the car was tasted during a summer mid-day for the electric vehicle only and for EV with PV of poly-crystalline type. It indicated that the electric vehicle run for 400 meters in range and this occurs in 2 hours exactly. However, the range of movement for the electric vehicle with PV cell was 480 meters that occurs in 2 hours and 30 minutes as shown clearly in Table 1 . 


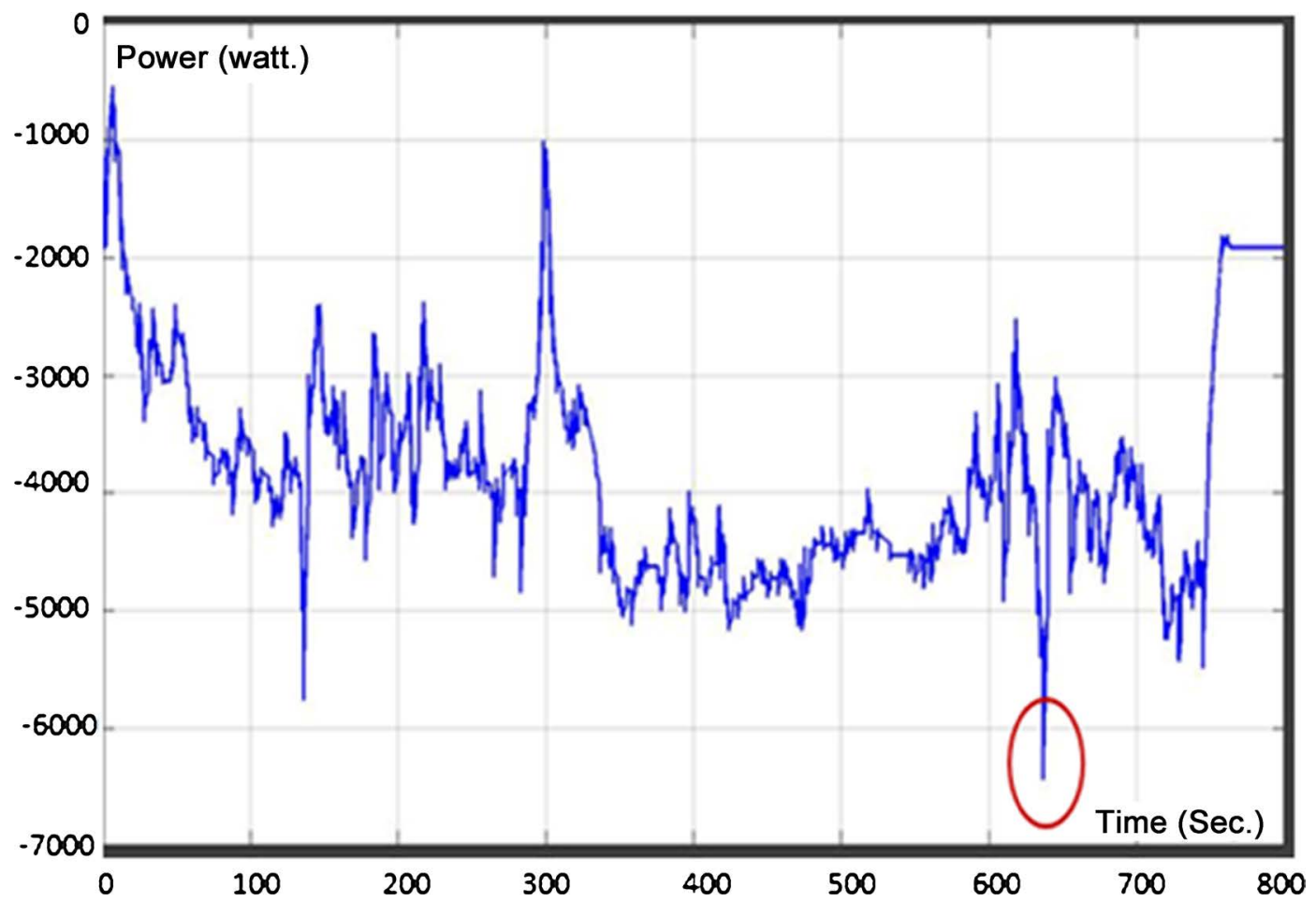

Figure 27. Photovoltaic vehicle battery power.

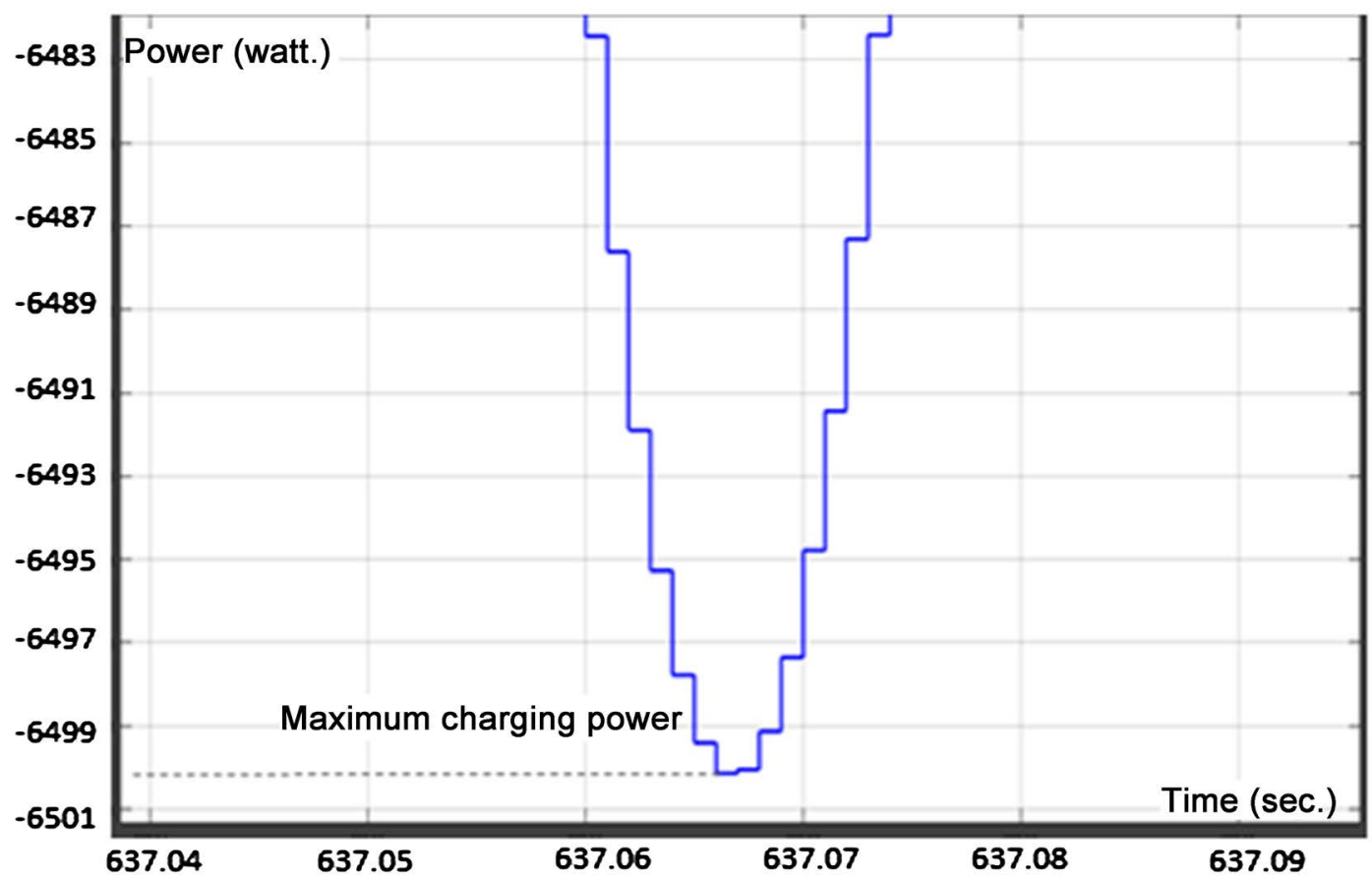

Figure 28. Zoom of battery power.

Table 1. Results of experimental work.

\begin{tabular}{ccc}
\hline & Electric model & Photovoltaic model \\
\hline Range & $400 \mathrm{~m}$. & $480 \mathrm{~m}$. \\
Empty battery time & $2 \mathrm{hrs}$. & 2 hrs. and 30 minutes. \\
\hline
\end{tabular}


This is to confirm that the EV with PV cell added extra working time about $25 \%$ of the EV working time. It also added extra $20 \%$ of the EV stroke.

\section{Conclusions}

From the previous results and discussions, these points can be concluded;

1) The electric vehicle (EV) has a braking performance better than the internal combustion engine (ICE). However, the acceleration performance of ICE is better than that of EVs.

2) Maximum battery power consumption rate of EV equals $+1500 \mathrm{~W}$. The positive sign means that the battery is discharging.

3) The photovoltaic vehicle (PV) has a braking performance better than the internal combustion engine (ICE). However, the acceleration for both PV and ICE is equal.

4) Maximum battery power consumption rate of PVs equals $-6500 \mathrm{~W}$. The negative sign means that the battery is charged by sun. The real saved battery power value equals $5000 \mathrm{~W}$.

5) The range of movement for the electric vehicle with PV cell is better than the EV by $20 \%$.

The working time for the electrical vehicle with PV cell is enhanced by $25 \%$ of the working time for the EV.

\section{References}

[1] Rizzo, G., Arsie, I. and Sorrentino, M. (2010) Solar Energy for Cars: Perspectives, Opportunities and Problems. GTAA Meeting, Mulhouse, 26-27 May 2010.

[2] Kyoto Protocol (2008) Status of Ratification. United Nations Framework Convention on Climate Change.

http://unfccc.int/files/kyoto_protocol/status_of_ratification/application/pdf/kp_rati fication.pdf

[3] http://Enanmearms.com/the-2014-oil-price-crash-explained

[4] http://Nea.polis.net/2014/10/22/on-public-health-and-energy

[5] http://www.treehugger.com/renewable-energy/striking-chart-showing-solar-powerwill-take-over-world.html

[6] Brain, M. (2002) How Electric Cars Work. http://auto.howstuffworks.com/electric-car2.htm

[7] Holms, A. and Argueta, R. (2010) A Technical Research Report: The Electric Vehicle.

[8] Majumder, S.G., Alam, T., Uddin, A. and Zubair, A. (2010) Environment Friendly Solar Car. BRAC University, Dhaka, 12.

[9] https://www.ucar.edu/learn/1_5_2_23t.htm

[10] Olivia, M. Fundamentals of Photovoltaic Materials. National Solar Power Research Institute, Inc., 2.

[11] https://www.colourbox.com/browse/energy/solar-energy/217

[12] Sabri, L. and Benzirar, M. (2014) Effect of Ambient Conditions on Thermal Properties of Photovoltaic Cells: Crystalline and Amorphous Silicon. International Journal of Innovative Research in Science, Engineering and Technology, 3, 17815-17821. https://doi.org/10.15680/IJIRSET.2014.0312010 